\title{
Role of oxidative stress in methamphetamine-induced dopaminergic toxicity mediated by protein kinase $\mathrm{C} \delta$
}

\author{
Eun-Joo Shin $\#$, Chu Xuan Duong ${ }^{\# a}$, Xuan-Khanh Thi Nguyena ${ }^{a}$, Zhengyi Lia, Guoying \\ Bing $^{b}$, Jae-Hyung Bach ${ }^{a}$, Dae Hun Park ${ }^{a}$, Keiichi Nakayama ${ }^{c}$, Syed F. Alid, Anumantha G. \\ Kanthasamy ${ }^{\mathrm{e}}$, Jean Lud Cadet $^{\dagger}$, Toshitaka Nabeshima $^{\mathrm{g}}$, and Hyoung-Chun Kim ${ }^{\mathrm{a},{ }^{*}}$ \\ aNeuropsychopharmacology and Toxicology Program, College of Pharmacy, Kangwon National \\ University, Chunchon 200-701, South Korea \\ bepartment of Anatomy and Neurobiology, College of Medicine, University of Kentucky, \\ Lexington, KY 40536, USA \\ 'Department of Molecular and Cellular Biology, Medical Institute of Bioregulation, Kyushu \\ University, Fukuoka 812-8582, Japan \\ dDivision of Neurotoxicology, National Center of Toxicological Research, FDA, Jefferson, \\ Arkansas 72079, USA \\ eParkinson's Disorder Research Laboratory, lowa Center for Advanced Neurotoxicology, \\ Department of Biomedical Sciences, lowa State University, Ames, IA 50011, USA \\ ${ }^{f}$ Molecular Neuropsychiatry Research Branch, DHHS/NIH/NIDA Intramural Research Program, \\ Baltimore, MD 21224, USA \\ gDepartment of Regional Pharmaceutical Care and Sciences and Department of Chemical \\ Pharmacology, Graduate School of Pharmaceutical Sciences, Meijo University, Nagoya \\ 468-8503, Japan \\ \# These authors contributed equally to this work.
}

\section{Abstract}

This study examined the role of protein kinase $\mathrm{C}(\mathrm{PKC})$ isozymes in methamphetamine (MA)induced dopaminergic toxicity. Multiple-dose administration of MA did not significantly alter $\mathrm{PKCa}, \mathrm{PKC} \beta \mathrm{I}, \mathrm{PKC} \beta \mathrm{II}$, or PKC $\zeta$ expression in the striatum, but did significantly increase $\mathrm{PKC} \delta$ expression. Gö6976 (a co-inhibitor of PKCa and - $\beta$ ), hispidin (PKC $\beta$ inhibitor), and $\mathrm{PKC} \zeta$ pseudosubstrate inhibitor ( $\mathrm{PKC} \zeta$ inhibitor) did not significantly alter MA-induced behavioral impairments. However, rottlerin (PKC $\delta$ inhibitor) significantly attenuated behavioral impairments in a dose-dependent manner. In addition, MA-induced behavioral impairments were not apparent in $\mathrm{PKC} \delta$ knockout (-I-) mice. MA-induced oxidative stress (i.e., lipid peroxidation and protein oxidation) was significantly attenuated in rottlerin-treated mice and was not apparent in PKC $\delta$ $(-/-)$ mice. Consistent with this, MA-induced apoptosis (i.e., terminal deoxynucleotidyl transferase-mediated dUTP nick-end labeling-positive apoptotic cells) was significantly attenuated in rottlerin-treated mice. Furthermore, MA-induced increases in the dopamine (DA) turnover rate and decreases in tyrosine hydroxylase $(\mathrm{TH})$ activity and the expression of $\mathrm{TH}$, dopamine

\footnotetext{
*Corresponding author at: Neuropsychopharmacology and Toxicology Program, College of Pharmacy, Kangwon National University, Chunchon 200-701, South Korea. Tel: +82-33-250-6917; Fax: +82-33-255-7865. kimhc@ kangwon.ac.kr (H.-C. Kim)..

Chu Xuan Duong's present address; Cantho University of Medicine and Pharmacy, Cantho City, Vietnam

Conflict of interest

No authors have conflict of interest to declare.
} 
transporter (DAT), and vesicular monoamine transporter 2 (VMAT2) were not significantly observed in rottlerin-treated or $\operatorname{PKC} \delta(-/-)$ mice. Our results suggest that $P K C \delta$ gene expression is a key mediator of oxidative stress and dopaminergic damage induced by MA. Thus, inhibition of PKC $\delta$ may be a useful target for protection against MA-induced neurotoxicity.

\section{Keywords}

Methamphetamine; PKC isozymes; PKC $\delta$ gene deletion; Rottlerin; dopamine; oxidative stress

\section{Introduction}

Abuse of the illegal psychostimulant methamphetamine (MA) has become an international public health problem with an estimated 15 to 16 million users worldwide [1, 2]. MA abuse is associated with numerous negative effects, including acute toxicity, altered behavioral and cognitive function, and neurological damage $[3,4]$. Ingestion of large doses of the drug can cause more serious consequences, including life-threatening hyperthermia, renal and hepatic failure, heart attacks, cerebrovascular hemorrhage, strokes, and seizures $[3,5,6]$. There is compelling evidence to suggest that the negative neuropsychiatric consequences of MA abuse are caused, at least in part, by drug-induced neuropathological changes in the brains of MA-exposed individuals [4].

The $4 \times 7-10 \mathrm{mg} / \mathrm{kg}$ paradigm of methamphetamine (MA) administration in naïve animals is currently the most frequently used model that mimics acute toxic dosing of MA [1, 7-9]. This paradigm provides excellent relevance to intravenous and smoked routes of MA exposure in humans. In addition, it demonstrates the toxic effects of MA in non-tolerant users $[8,10]$. Conversely, Cadet et al. [11] used a regimen that involved gradual increases in MA administration to rats to mimic progressively larger doses of drug used by some human MA addicts. They found that this MA preconditioning was associated with significant protection against dopamine depletion caused by acute MA challenges. However, MA pretreatment does not completely abrogate the degenerative effects of the drug on dopamine terminals, as evidence still exists regarding MA challenge-induced decreases in DA levels in the rat striatum. Free radical formation and microglial activation are thought to be involved in the long-term toxic effects of MA [12,13]; therefore, the cellular and molecular mechanisms underlying MA pretreatment-mediated attenuation of MA challenge-induced toxic responses on the striatal DA system remain to be further explored.

Indeed, increased levels of the lipid peroxidation products 4-hydroxynonenal (4-HNE) and malondialdehyde (MDA) have been reported in the caudate nuclei and prefrontal cortices of chronic MA users [14-16]. LaVoie and Hastings [17] found that administration of neurotoxic doses of MA to rats caused DA oxidation of DA quinones that bind to cysteinyl residues on proteins, leading to an increase in protein cysteinyl-DA levels in the striatum. These findings suggest that DA oxidation may contribute to MA-induced damage to DA terminals [17]. Furthermore, accumulated evidence indicates that MA can also cause oxidative stress by shifting the balance between reactive oxygen species (ROS) production and the capacity of antioxidant systems to scavenge ROS [7, 18-21].

The protein kinase $\mathrm{C}$ (PKC) family consists of serine/threonine kinases, broadly classified into three subgroups based on their sensitivity to important cofactors, which include phospholipids and $\mathrm{Ca}^{2+}[22,23]$. The conventional PKC isoforms $(\mathrm{a}, \beta \mathrm{I}, \beta \mathrm{II}$, and $\gamma)$ are sensitive to $\mathrm{Ca}^{2+}$ and diacylglycerol, whereas the novel isoforms $(\delta, \varepsilon, \eta, \theta$, and $\mu)$ are $\mathrm{Ca}^{2+}$ independent, but require diacylglycerol for activation. The atypical isoforms $(\zeta$ and $\mathrm{u} / \lambda)$ require neither $\mathrm{Ca}^{2+}$ nor diacylglycerol for activation. PKC isoforms are differentially 
distributed in tissues and play key roles in various cellular biological processes, including cell differentiation, cell growth, cellular redox status, apoptosis, tumor suppression, and carcinogenesis.

Earlier evidence has indicated that PKC-mediated signaling is activated by oxidants (peroxide) that selectively react with the PKC regulatory domain; signaling is inhibited by antioxidants reacting with the catalytic domain [24-25]. Previous reports showed that pathophysiological concentrations of 4-HNE specifically activated PKC- $\beta$ isoforms in different cell systems modulating protein transport and secretion [26, 27]. Domencotti et al. [28] found that a decrease in cellular glutathione was accompanied by the inactivation of classic isoforms and increased activity of novel PKCs.

Interestingly, Pubill et al. [29] demonstrated that a specific PKC inhibitor, NPC 15437, completely inhibited MA-induced ROS formation in rat striatal synaptosomes, corroborating a key role for PKC in this process. Moreover, evidence has shown that PKC contributes to amphetamine-stimulated DA release. A PKC activator, phorbol ester 12-Otetradecanoylphorbol-13-acetate (TPA), mimics the effect of amphetamine by increasing DA release in striatal slices and synaptosomes [30]. Conversely, a nonspecific PKC inhibitor, Ro31-8220, blocks $\mathrm{Ca}^{2+}$-independent amphetamine-induced dopamine release in rat striatal slices [31]. Similarly, the selective PKC inhibitor chelerythrine completely inhibits endogenous DA release induced by amphetamine [32].

However, little is known regarding the role of individual PKC isozymes in in vivo da DAergic alterations induced by an amphetamine analog. Thus, we sought to examine, in advance, whether the $P K C$ gene is also involved in oxidative stress and dopaminergic toxicity induced by acute toxic dosing of MA. We examined the role of various PKC isozymes in MA neurotoxicity (including behavioral impairments) in mice. We observed that, of the PKC isozymes examined, $\mathrm{PKC} \delta$ was primarily involved in MA-induced DAergic toxicity. We corroborated these results by demonstrating that both PKC $\delta$ inhibition (using rottlerin, a PKC $\delta$ inhibitor) and $P K C \delta$ gene knockout attenuate oxidative stress and DAergic damage induced by acute toxic dosing of MA.

\section{Materials and Methods}

\subsection{Animals}

All mice were treated in accordance with the NIH Guide for the Humane Care and Use of Laboratory Animals. They were maintained on a 12/12-h light/dark cycle and fed ad libitum. They were adapted to these conditions for 2 weeks before the experiment. The experimental schedules are shown in Fig. 1.

\subsection{Development and characterization of PKC $(-/-)$ mice}

A breeding pair of $\mathrm{PKC} \delta(+/-)$ mice, originally bred into a C57BL/6 background, was a gift from Dr. K. I. Nakayama (Dept. of Molecular Genetics, Medical Institute of Bioregulation, Kyushu University, Fukuoka, Japan) [33]. These mice were subsequently maintained and bred into the C57BL/6 background for 3 to 6 generations in a specific pathogen-free (SPF) facility before use with wild-type mice from the same litter in our experiments. Tail DNA was evaluated and typed using polymerase chain reaction (PCR) and primers for PKC $\delta$ obtained from Bioneer Corporation (Daejeon, South Korea). PCR Primers for genotyping were as follows; 5'-GGAAGAATAAGAAACTGCATCACC-5' and 5'GAAGGAGCCAGAACCGAAAG-3' for endogenous detection, and 5'GGAAGAATAAGAAACTGCATCACC-3' and 5'-TGGGGTGGGATTAGATAAATG-3' for mutant detection. Brain tissue from $\mathrm{PKC} \delta(-/-)$ mice was examined by Western blot 
analyses using antibodies for PKC $\delta$ and other isoforms ( $\alpha, \beta \mathrm{I}, \beta \mathrm{II}, \zeta$; Santa Cruz

Biotechnology, Inc., Santa Cruz, CA, USA) to confirm that PKC $\delta$ protein was selectively absent in PKCS (-/-) mice and that expression of the other isoforms was normal.

\subsection{Guide cannula implantation and intracerebroventricular (i.c.v.) infusion}

Mice were anesthetized with pentobarbital (40 mg/kg, i.p.) and placed in a stereotaxic apparatus (David Kopf Instruments, Tujunga, CA, USA). A stainless steel guide cannula (AG-4; Eicom, Kyoto, Japan) was implanted into the right lateral ventricle (stereotaxic coordinates: $0.5 \mathrm{~mm}$ posterior to bregma, $1 \mathrm{~mm}$ right to the midline, and $2 \mathrm{~mm}$ ventral to the dura, according to the atlas of Paxinos [34]) [35]. No histological or mechanical disruption was produced by implantation of the infusion cannula (data not shown). Microinfusion into the lateral ventricle was performed through a microinfusion cannula (AMI-4, Eicom, Kyoto, Japan) at a rate of $1 \mu \mathrm{L} / \mathrm{min}$ using a microinjection pump (CMA/100, CMA, Solna, Sweden). The microinfusion cannula was kept in place for $1 \mathrm{~min}$ after infusion to avoid backflow. Guide cannula implantation did not affect the behaviour of the subjects.

Subsequent to guide cannula implantation, each animal was housed in a single cage in order to safely maintain the integrity of the implantation during the experimental period.

\subsection{Intracerebroventricular infusion of $P K C$ inhibitors and treatment with methamphetamine (MA)}

Gö6976 (co-inhibitor of PKC a and $\beta$; Calbiochem, La Jolla, CA, USA), hispidin (PKC $\beta$ inhibitor; Calbiochem, La Jolla, CA, USA), rottlerin (PKC $\delta$ inhibitor; Biomol Research Laboratories Inc., Plymouth, PA, USA), or $\mathrm{PKC} \zeta$ pseudosubstrate (PKC $\zeta$ inhibitor; Tocris Bioscience, Ellisville, MO, USA) was dissolved in DMSO as a stock solution, and then stored at $-20^{\circ} \mathrm{C}$. Each PKC inhibitor was diluted in sterile saline immediately before use at a concentration of $1.0 \mu \mathrm{g} / \mu \mathrm{l}$. The final DMSO concentration was $10 \%(\mathrm{v} / \mathrm{v})$. After two days of recovery from the guide cannula implantation, mice were microinfused into the lateral ventricle with Gö6976 (1.0 or $2.0 \mu \mathrm{g})$, hispidin $(1.5$ or $3.0 \mu \mathrm{g})$, rottlerin $(1.5$ or $3.0 \mu \mathrm{g})$, or PKC $\zeta$ pseudosubstrate inhibitor $(1.5$ or $3.0 \mu \mathrm{g})$ once a day for 5 days. On next day, mice received four times of MA $(8 \mathrm{mg} / \mathrm{kg}$, i.p.) or saline as a $2 \mathrm{hr}$-time interval. Additional microinfusion of each PKC inhibitor was performed 4 -h and 0.5 -h before the $1^{\text {st }} \mathrm{MA}$ injection (Fig. 1A). The doses of PKC inhibitors used in this study were determined based on previous studies [36, 37] and our pilot study [38].

\subsection{Locomotor activity}

Locomotor activity was measured for 30 min 3 days after the last MA administration using an automated video-tracking system (Noldus Information Technology, Wagenin, The Netherlands). Four test boxes $(40 \times 40 \times 30 \mathrm{~cm}$ high $)$ were operated simultaneously by an IBM computer. Mice were studied individually during locomotion in each test box, where they were adapted for 5 min before starting the experiment. A printout for each session showed the pattern of the ambulatory movements of the test box. The distance traveled in $\mathrm{cm}$ by the animals in horizontal locomotor activity was analyzed. Data were collected and analyzed between 09:00 and 17:00 h [39].

\subsection{Rota-rod test}

Rota-rod test was performed 1 hour after locomotor activity measurement. The apparatus (Ugo Basile model 7650, Comerio, VA, Italy) consisted of a base platform and a rotating rod with a non-slippery surface. The rod was placed at a height of $15 \mathrm{~cm}$ from the base. The rod, $30 \mathrm{~cm}$ in length, was divided into 5 equal sections by 6 opaque disks (so that the subjects cannot be distracted by one another). To assess motor performance, the mice first trained on the apparatus for 2 minutes at a constant rate of 4 r.p.m. The test was performed 
30 minutes after training and an accelerating paradigm was applied, starting from a rate of 4 r.p.m. to a maximum speed of 40 r.p.m., then the rotation speed was kept constant at 40 r.p.m. for a maximum of $300 \mathrm{~s}$. The duration for which the animal could maintain balance on the rotating drum was measured as the latency to fall, with a maximal cut-off time of 300 s [39].

\subsection{Immunocytochemistry for tyrosine hydroxylase (TH)}

Animals were sacrificed at 4 hours and 3 days after the last MA injection. They were anesthetized with $60 \%$ urethane and perfused transcardially with $50 \mathrm{ml}$ of $50 \mathrm{mM}$ phosphate buffered saline (PBS), followed by $50 \mathrm{ml}$ of a mixture of $4 \%$ paraformaldehyde in PBS. The rate of perfusion was $10 \mathrm{ml} / \mathrm{min}$. The brains were removed, post-fixed at $4^{\circ} \mathrm{C}$ for $24 \mathrm{~h}$ in the same fixative and then cryoprotected in $30 \%$ sucrose in PBS. The brains were cut on a horizontal sliding microtome into $30 \mu \mathrm{m}$ transverse free-floating sections [40-43].

The immunocytochemistry was performed as described previously [39]. Every sixth section throughout the entire extent of the striatum was collected for TH immunostaining. Briefly, prior to incubation with the primary antibodies, sections were preincubated with $0.3 \%$ hydrogen peroxide in PBS for 30 min (to block endogenous peroxidase activity), then in PBS containing $0.4 \%$ Triton X-100 and $1 \%$ normal serum for $20 \mathrm{~min}$. The sections were then incubated for $48 \mathrm{~h}$ at $4^{\circ} \mathrm{C}$ in primary antibody against $\mathrm{TH}$ (1:500, Chemicon, Temecula, CA, USA). The sections were further incubated with secondary biotinylated antisera (1:1000 dilution; Vector, Burlingame, $\mathrm{CA}$ ) for $1 \mathrm{~h}$, and immersed in avidin-biotin-peroxidase complex (ABC Elite kit, Vector) for $1 \mathrm{~h}$. Sections were always washed three times with PBS (pH 7.4) between each incubation step. 3,3'-diaminobenzidine (DAB) was used as a chromogen.

Digital images were acquired on an Olympus microscope (BX51, Olympus ${ }^{\circledR}$, Tokyo, Japan) using digital microscope camera (DP72, Olympus ${ }^{\circledR}$, Tokyo, Japan), and IBM PC. A region of interest (ROI) was created and the immunoreactive density of striatal TH was measured by Optimas ${ }^{\circledR}$ version 6.51 software (Media Cybernetics, Inc. Silver Spring, MD, USA).

\subsection{Synaptosome preparation}

Striatal tissue was homogenized in 10 volume of ice-cold $0.32 \mathrm{~mol} / \mathrm{L}$ sucrose and centrifuged at low speed $\left(800 \times \mathrm{g}, 12 \mathrm{~min}, 4^{\circ} \mathrm{C}\right)$. This resulted in supernatant $(\mathrm{S} 1)$ that was removed and centrifuged at high speed $\left(22,000 \times \mathrm{g}, 20 \mathrm{~min}, 4^{\circ} \mathrm{C}\right)$ in order to yield pelleted synaptosomes. An aliquot of the re-suspended (P2) synaptosomal fraction was used for western analysis $[44,45]$.

\subsection{Western blot analysis}

The Western blot assay was performed as described previously [39, 43, 46]. For evaluating tyrosine hydroxylase $(\mathrm{TH})$ expression, striatal tissues were homogenized in lysis buffer containing $200 \mathrm{mM}$ Tris $\mathrm{HCl}$ (pH 6.8), $1 \%$ sodium dodecyl sulfate (SDS), $5 \mathrm{mM}$ ethylene glycol-bis(2-aminoethyl ether)-N,N,N $\mathrm{N}^{\prime} \mathrm{N}^{\prime}$-tetraacetic acid (EGTA), $5 \mathrm{mM}$ ethylenediaminetetraacetic acid (EDTA), $10 \%$ glycerol, $1 \times$ phosphatase inhibitor cocktail I (Sigma-Aldrich, St. Louis, MO, USA), and $1 \times$ protease inhibitor cocktail (Sigma). The lysate was centrifuged at $12,000 \times \mathrm{g}$ for $30 \mathrm{~min}$ and the supernatant fraction was used. The synaptosomal fraction or lysate (20-50 $\mu \mathrm{g}$ protein/lane) was separated by $8 \%$ or $10 \%$ SDSpolyacrylamide gel electrophoresis (SDS-PAGE) and transferred onto polyvinylidene (PVDF) membranes. Following transfer, the membranes were preincubated with 5\% non-fat milk for $30 \mathrm{~min}$ and incubated overnight at $4^{\circ} \mathrm{C}$ with a primary antibody against $\mathrm{TH}$ (1:5000), dopamine transporter (DAT) (1:5000; Chemicon International, Inc., Temecula, CA, USA), vesicular monoamine transporter 2 (VMAT2) (1:500; Novus Biologicals, 
Littleton, CO, USA), or $\beta$-actin (1:50000; Sigma). Membranes were then incubated with horseradish peroxidase (HRP)-conjugated secondary anti-rabbit IgG (1:1000; GE Healthcare, Piscataway, NJ, USA), anti-mouse IgG (1:1000; Sigma), or anti-goat IgG $\left(1: 1000\right.$; Sigma) for $2 \mathrm{~h}$. Subsequent visualization was performed using the ECL plus ${ }^{\circledR}$ enhanced chemiluminescence system (GE Healthcare). Relative band intensities were quantified using PhotoCapt MW (version 10.01 for Windows; Vilber Lourmat, Marne la Vallée, France), and the intensity of TH, DAT, or VMAT2 was then normalized to $\beta$-actin intensity.

\subsection{Measurement of dopamine (DA), 3,4-dihydroxyphenylacetic acid (DOPAC) and homovanillic acid (HVA)}

Mice were sacrificed 3 days after the last MA injection. The striatum was dissected out and immediately frozen on dry ice, and stored at $-70{ }^{\circ} \mathrm{C}$ until extraction. The striatum obtained from each animal was weighed, ultrasonicated in $10 \%$ perchloric acid containing $10 \mathrm{ng} / \mathrm{mg}$ of the internal standard dihydroxybenzylamine, and centrifuged at 20,000 $\times \mathrm{g}$ for $10 \mathrm{~min}$. The levels of DA and its metabolites 3,4-dihydroxyphenylacetic acid (DOPAC) and homovanillic acid (HVA) were determined by HPLC coupled with electrochemical detection as described $[39,47,48]$. The $20 \mu \mathrm{l}$ aliquot of the supernatant was injected into the HPLC equipped with a $3 \mu \mathrm{m} \mathrm{C} 18$ column. The mobile phase was comprised of $26 \mathrm{ml}$ of acetonitrile, $21 \mathrm{ml}$ of tetrahydrofuran and $960 \mathrm{ml}$ of $0.15 \mathrm{M}$ monochloroacetic acid (pH 3.0) containing $50 \mathrm{mg} / \mathrm{l}$ of EDTA and $200 \mathrm{mg} / \mathrm{l}$ of sodium octyl sulfate. The amount of DA, DOPAC and HVA were determined by comparison of peak area of tissue sample with standard, and were expressed in micrograms per gram of wet tissue.

\subsection{Measurement of Tyrosine Hydroxylase (TH) Activity}

TH activity was measured according to the method of Nagatsu et al. [49] with slight modification [38]. Briefly, the striatum was homogenized in ice-cold $0.05 \mathrm{M}$ sodium acetate

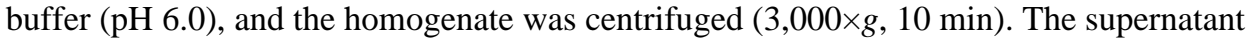
was added to reaction mixture containing $100 \mathrm{mM}$ acetate buffer (pH 6.0), $200 \mu \mathrm{M} \mathrm{L}$ tyrosine, $1.25 \mathrm{mM} \mathrm{m}$-hydroxybenzylhydrazine (NSD-1015), $1.0 \mathrm{mM}$ 6methyltetrahydropterine, $19.5 \times 10^{3} \mathrm{U} / \mathrm{mL}$ catalase, $3.8 \mathrm{mU} / \mathrm{mL}$ dihydropteridine reductase, $1 \mathrm{mM}$ NADPH, and $0.2 \mathrm{M}$ glycerol. Reactions were incubated for $10 \mathrm{~min}$ at $37^{\circ} \mathrm{C}$ and were terminated by the addition of $0.4 \mathrm{M}$ perchloric acid. Then, the reaction mixture was passed through an alumina cartridge using $0.5 \mathrm{M} \mathrm{HCl}$, and the eluent was injected into a HPLC apparatus equipped with electrochemical detector (ECD-300, Eicom, Kyoto, Japan). Chromatographic separation was conducted using a 5- $\mu \mathrm{m}$ C18 reverse-phase ODS column (Axxiom Chromatography, Moonpark, CA, USA). The mobile phase ( $\mathrm{pH} 3.35$ ) consisted of $0.1 \mathrm{M} \mathrm{NaH}_{2} \mathrm{PO}_{4}, 0.13 \mathrm{mM}$ EDTA, $0.22 \mathrm{mM}$ octane sulfonate, and $2.5 \%$ acetonitrile. TH activity was expressed as pmole of DOPA formation per mg wet tissue per minute.

\subsection{Determination of malondialdehyde by HPLC}

The amount of lipid peroxidation was determined by measuring the accumulation of thiobarbituric acid-reactive substances in homogenates of the striatum and is expressed in terms of malondialdehyde (MDA) content. The amount of MDA in homogenates of striatum was determined by the methods of Jareno et al. [50] with some modification [7, 51]. In brief, $0.1 \mathrm{ml}$ of the homogenate diluted 10 times with phosphate buffered saline (PBS) was mixed with $0.75 \mathrm{ml}$ working solution (thiobarbituric acid $0.37 \%$ and perchloric acid $6.4 \%, 2: 1$, v/v) and heated to $95{ }^{\circ} \mathrm{C}$ for $1 \mathrm{~h}$. After cooling ( $10 \mathrm{~min}$ in ice water bath), the flocculent precipitate was removed by centrifugation at $3200 \times g$ for $10 \mathrm{~min}$. The supernatant was neutralized and filtered prior to injection on an octadecylsilane $5 \mu \mathrm{m}$ column. Mobile phase consisted of $50 \mathrm{mM}$ PBS (pH 6.0): methanol (58:42, v/v). Isocratic separation was 
performed with $1.0 \mathrm{ml} / \mathrm{min}$ flow rate and detection at $532 \mathrm{~nm}$ using a UV/VIS highperformance liquid chromatography detector (HPLC)-Detector (Model 486, Waters Associates, Milford, MA, USA).

\subsection{Determination of protein carbonyl by biochemical assay}

The extent of protein oxidation in the striatum was assessed by measuring the content of protein carbonyl groups, which was determined spectrophotometrically with the 2,4dinitrophenylhydrazine (DNPH)-labeling procedure as described by Oliver et al. [52]. The results are expressed as nmol of DNPH incorporated/mg protein [51] based on the extinction coefficient for aliphatic hydrazones of $21 \mathrm{mM}^{-1} \mathrm{~cm}^{-1}$.

\subsection{Determination of 4-hydroxy-2-nonenal (4-HNE) and protein carbonyl by slot blot analysis}

4-Hydroxy-2-nonenal (4-HNE) is major product of the lipid peroxidation process [53]. Determining of 4-HNE was performed as slot blot analysis [41]. Tissue lysates were prepared as described in the western blot analysis. Two hundred $\mu \mathrm{g}$ of protein was loaded into each well and adsorbed onto the PVDF membrane using a slot blot apparatus (Hoefer Scientific Instruments, Model PR648, San Francisco, CA, USA). Following adsorption, the PVDF membranes were preincubated with $5 \%$ non-fat milk and incubated overnight at $4{ }^{\circ} \mathrm{C}$ with anti-4-HNE (1:2000, Calbiochem). After incubation with primary antibody, membranes were incubated with a HRP-conjugated secondary antibody. Subsequent visualization was performed using enhanced chemiluminescence system (ECL plus®, GE healthcare).

The amount of oxidized proteins was measured using the Oxyblot kit (Chemicon) according to the instruction provided by manufacturer. Briefly, the protein carbonyl content was labeled by protein hydrazone derivatives using 2,4-dinitrophenylhydrazide (DNP). Fifty $\mu \mathrm{g}$ of DNP-derivatized protein sample was loaded in each well and adsorbed onto PVDF membrane by slot blot apparatus (Hoefer Scientific Instruments). Each blot was preincubated with $5 \%$ non-fat milk then incubated with primary antibody $(1: 100)$ specific to the DNP moiety, which is provided in the kit. After incubation with a HRP-conjugated secondary antibody, subsequent visualization was performed using enhanced chemiluminescence system (ECL plus®, GE healthcare) [41].

\subsection{Terminal deoxynucleotidyl transferase-mediated dUTP nick-end labeling (TUNEL) staining}

TUNEL staining was performed using the FragEL DNA fragmentation detection kit (QIA33; Calbiochem, La Jolla, CA, USA) according to the manufacturer's protocol. Briefly, sections were permeabilized by incubation with $20 \mathrm{mg} / \mathrm{ml}$ proteinase $\mathrm{K}$, and then incubated with $3 \%$ hydrogen peroxide to block endogenous peroxidase activity. After immersion in the terminal deoxynucleotidyl transferase (TdT) equilibration buffer, sections were incubated with biotinylated deoxynucleotides and TdT enzyme. Sections were then immersed in streptavidin-peroxidase complex with diaminobenzidine tetrahydrochloride as the chromogen. Counterstaining was performed using methyl green, which was provided in the kit. Digital images were acquired at $40 \times$ or $200 \times$ magnification using an Olympus microscope (BX51; Olympus, Center Valley, PA, USA) and a digital microscope camera (DP72; Olympus) [54].

\subsection{Statistical analyses}

Data were analyzed using a one-way ANOVA followed by Fischer's PLSD test. $P$-values of less than 0.05 were deemed to indicate statistical significance. 


\section{Results}

\subsection{Effects of MA on the expression of PKC isozymes}

It is known that PKC modulates the release of DA in the nigrostriatal pathway. This is supported by the fact that injections of drugs that affect DA release in vivo result in changes in PKC activity in the striatum $[55,56]$. We examined the striatal expression of PKC isozymes after the final MA dose. Expression of striatal PKCa, $\beta \mathrm{I}, \beta \mathrm{II}, \zeta$, and $\delta$ was examined $4 \mathrm{~h}, 3 \mathrm{~d}$ and $14 \mathrm{~d}$ after the final MA administration in C57BL/6 mice. The effect of PKC inhibitors on MA-induced PKCa, $\beta \mathrm{I}, \beta \mathrm{II}, \zeta$, and $\delta$ expression was also examined.

No significant difference in PKCa expression was observed between saline/vehicle and MA treatments. Furthermore, Gö6976 (1.0 or $2.0 \mu$ g, i.c.v.), a coinhibitor of PKCa and $-\beta$, did not significantly alter PKC a expression at $4 \mathrm{~h}, 3 \mathrm{~d}$ or $14 \mathrm{~d}$ after the final MA dose (Fig. 2A).

Treatment with MA appeared to increase PKC $\beta I$ and PKC $\beta I I$ expression, although this change was not statistically significant. Neither Gö6976 (2.0 $\mu \mathrm{g}$, i.c.v.) nor hispidin $(3.0 \mu \mathrm{g}$, i.c.v.) significantly altered PKC $\beta \mathrm{I}$ or PKC $\beta I$ II expression at $4 \mathrm{~h}, 3 \mathrm{~d}$ or $14 \mathrm{~d}$ after the final MA dose (Fig. 2B, C). Treatment with MA did not significantly induce PKC $\zeta$. Furthermore, $\mathrm{PKC} \zeta$ pseudosubstrate inhibitor (1.5. or $3.0 \mu$ g, i.c.v.) did not affect $\mathrm{PKC} \zeta$ expression at $4 \mathrm{~h}$, $3 \mathrm{~d}$ or14 d after the final MA dose (Fig. 2D).

The duration of the significant MA-induced increase in PKC $\delta$ expression was at least 14 days $(P<0.01)$. Vehicle or rottlerin treatment did not affect PKC $\delta$ expression. Rottlerin $[1.5$ or $3.0 \mu \mathrm{g}$, intracerebroventricularly (i.c.v.)] significantly attenuated MA-induced PKC $\delta$ expression in a dose- and time-dependent manner $(4 \mathrm{~h}, 3 \mathrm{~d}$, and $14 \mathrm{~d}$ post-MA; Veh + MA vs. $1.5 \mu \mathrm{g}$ rottlerin + MA or $3.0 \mu \mathrm{g}$ rottlerin + MA; $P<0.05$ or $P<0.01$, respectively; Fig. 2E).

\subsection{PKCठ is involved in MA-induced behavioral impairments in mice}

Because MA-induced behavioral impairment is, at least in part, related to the dopaminergic degenerative effects of the drug, we measured locomotor activity and rota-rod performance in animals treated with various drug combinations (Fig. 3).

Significant decreases in locomotor activity $(P<0.01)$ and rota-rod performance $(P<0.01)$ were observed $3 \mathrm{~d}$ after the final MA administration. These decreases persisted [locomotor activity $(P<0.05)$ and rota-rod performance $(P<0.05)]$ for $14 \mathrm{~d}$ after the final MA administration. No significant changes in locomotor activity and rota-rod performance were observed in the absence of MA. Vehicle treatment did not affect behavioral impairments induced by MA.

The locomotor activity profile consistently paralleled that of rota-rod performance. Treatment with rottlerin, a PKC $\delta$ inhibitor, blocked these changes in both locomotor activity and rota-rod performance $(3 \mathrm{~d}$ after the final MA; Veh + MA vs. 1.5 or $3.0 \mu \mathrm{g}$ rottlerin + MA, $P<0.05$ or $P<0.01$, respectively; $14 \mathrm{~d}$ after the final MA; Veh + MA vs. $3.0 \mu \mathrm{g}$ rottlerin + MA, $P<0.05$ ).

Because the intracerebroventricular (i.c.v.) route is more effective than the oral (p.o.) route in obtaining the neuroprotective effects of rottlerin [38], we used an i.c.v. infusion (Fig. 3A, B). Results were comparable to those in MA-treated PKC $\delta(-l-)$ mice (data not shown). However, treatment with Gö6976 (a PKCa and PKC $\beta$ inhibitor), hispidin (a PKC $\beta$ inhibitor), and $\mathrm{PKC} \zeta$ pseudosubstrate inhibitor showed no significant effect on MA-induced behavioral impairment in mice. 


\subsection{Effects of rottlerin on MA-induced increases in DA turnover in the striata of PKC $\delta(+/+)$ mice: comparison with MA-treated PKC $\delta(-/-)$ mice}

Having shown that MA causes marked changes in PKC $\delta$ expression, we then examined the potential involvement of this isozyme in MA toxicity. MA treatment significantly decreased striatal DA levels [both at $3 \mathrm{~d}$ and $14 \mathrm{~d}$ post-MA: $P<0.01 \mathrm{vs}$. saline-treated PKC $\delta(+/+)$ mice; Fig. 4A]. MA also significantly decreased 3,4-dihydroxyphenylacetic acid (DOPAC; both at $3 \mathrm{~d}$ and $14 \mathrm{~d}$ post-MA: $P<0.05 v s$. saline-treated $\mathrm{PKC} \delta(+/+)$ mice; Fig. $4 \mathrm{C})$ and homovanillic acid (HVA; both at $3 \mathrm{~d}$ and $14 \mathrm{~d}$ post-MA: $P<0.05 v s$. saline-treated PKC $\delta$ $(+/+)$ mice; Fig. 4E). Furthermore, MA induced increases in the striatal DA turnover rate [(DOPAC + HVA)/DA; both at $3 \mathrm{~d}$ and $14 \mathrm{~d}$ post-MA: $P<0.01 v s$. saline-treated $\mathrm{PKC} \delta(+/$ $+)$ mice; Fig. 3G]. Rottlerin or vehicle treatment did not alter DA levels or the DA turnover rate. Additionally, vehicle treatment did not affect MA-induced dopaminergic (DAergic) changes. Rottlerin ( 1.5 or $3.0 \mu$ g, i.c.v.) significantly attenuated the MA-induced decrease in DA and increase in the DA turnover rate in a dose-dependent manner $(3 \mathrm{~d}$ post-MA; DA: Veh + MA vs. 1.5 or $3.0 \mu \mathrm{g}$ rottlerin + MA; $P<0.05$ or $P<0.01$, respectively; DA turnover rate: Veh + MA vs. 1.5 or $3.0 \mu \mathrm{g}$ rottlerin $+\mathrm{MA} ; P<0.05$ or $P<0.01$, respectively; $14 \mathrm{~d}$ post-MA; DA: Veh + MA vs. 1.5 or $3.0 \mu \mathrm{g}$ rottlerin + MA; $P<0.05$ or $P<0.01$, respectively; DA turnover rate: Veh + MA vs. 1.5 or $3.0 \mu \mathrm{g}$ rottlerin + MA; $P<0.05$ or $P<$ 0.05 , respectively. Fig. 4A, G).

We also used PKC $\delta$ knockout (-I-) mice to test whether elimination of the $P K C \delta$ gene protects against the toxic effects of MA. Knockout mice showed a smaller decrease in striatal DA levels as compared with MA-treated PKC $\delta(+/+)$ mice. DA levels in MA-treated $\operatorname{PKC} \delta(-/-)$ mice were significantly higher as compared with MA-treated PKC $\delta(+/+)$ mice [both $3 \mathrm{~d}$ and $14 \mathrm{~d}$ post-MA: MA-treated PKC $\delta(+/+)$ vs. MA-treated PKC $\delta(-/-) ; P<0.01$; Fig. 4B]. The MA-induced changes in DA turnover were also attenuated in $\operatorname{PKC} \delta(-/-)$ mice [both at $3 \mathrm{~d}$ and $14 \mathrm{~d}$ post-MA: MA-treated PKC $\delta(+/+) v s$. MA-treated PKC $\delta(-/-) ; P<$ 0.01 ; Fig. $4 \mathrm{H}]$.

\subsection{Effects of rottlerin on MA-induced decreases in TH-immunoreactivity (TH-IR), TH expression, and TH activity in the striata of PKCठ (+/+) mice: comparison with MA-treated PKCठ (-l-) mice}

Having demonstrated that PKC $\delta$ inhibition protects against striatal DA depletion, we examined whether PKC $\delta$ inhibition was similarly effective against the effects of MA on TH protein expression in the mouse striatum. In addition, we examined striatal TH activity using high-performance liquid chromatography (HPLC).

Figure 5A shows that MA significantly decreased striatal TH immunoreactivity (TH-IR) in PKC $\delta(+/+)$ mice ( $3 \mathrm{~d}$ and $14 \mathrm{~d}$ post-MA: Sal + Sal vs. Sal $+\mathrm{MA} ; P<0.01)$. The vehicle per se did not affect the MA-induced significant reduction in TH-IR. Pretreatment with rottlerin $(1.5$ or $3.0 \mu$ g, i.c.v.) significantly attenuated this MA-induced reduction in TH-IR dosedependently ( 3 d post-MA: Veh + MA vs. 1.5 or $3.0 \mu \mathrm{g}$ rottlerin + MA; $P<0.05$ or $P<$ 0.01 , respectively; $14 \mathrm{~d}$ post-MA: Veh + MA $v s .1 .5$ or $3.0 \mu \mathrm{g}$ rottlerin + MA; $P<0.05$ or $P$ $<0.05$, respectively; Fig. 5A). MA-induced reductions in TH-IR in the striatum were consistently less pronounced in $\mathrm{PKC} \delta(-/-)$ mice $[3 \mathrm{~d}$ or $14 \mathrm{~d}$ post-MA: MA-treated $\mathrm{PKC} \delta$ $(+/+)$ vs. MA-treated PKC $\delta(-/-) ; P<0.01$ or $\mathrm{P}<0.05$; Fig. 5B].

Western blot analyses were used to further evaluate the effects of MA on TH protein expression. The reduction in TH expression caused by MA was attenuated by rottlerin treatment (Fig. 5C) and in PKC $\delta(-/-)$ mice (Fig. 5D). 
As previously reported [57], MA injections markedly reduced TH activity (Fig. 5E, F). In terms of striatal TH activity, inhibition of PKC by rottlerin (Fig. 5E) and decreased PKC $\delta$ expression in $\mathrm{PKC} \delta(-/-)$ mice (Fig. 5F) both provided protection against MA-induced decreases in TH activity.

\subsection{Effects of rottlerin on MA-induced decreases in the expression of dopamine transporter (DAT) and vesicular monoamine transporter2 (VMAT2) in the striata of PKCס $(+/+)$ mice: comparison with MA-treated PKCס (-/-) mice}

DAT, a transmembrane protein, is involved in clearing dopamine from the synapse and returning it to the presynaptic terminals. VMAT2 transports dopamine, serotonin, and norepinephrine from the cytoplasm into specialized secretory vesicles. Using Western blotting, a previous study demonstrated that chronic MA users exhibited deficits in dopaminergic terminal markers [58]. Another study demonstrated the essential role that DA terminal markers play in MA-induced neurotoxicity [59], suggesting the importance of the balance between DAT- and VMAT2-mediated transport as a determinant of cell vulnerability to MA.

The MA-induced change in DAT and VMAT2 expression in the synaptosomal fraction of the striatum is shown in Figure 6. Treatment with MA resulted in a significant decrease in DAT expression. This decrease lasted at least $14 \mathrm{~d}$ after the final MA $(4 \mathrm{~h}, 3 \mathrm{~d}$, or $14 \mathrm{~d}$ postMA: Sal + Sal vs. Sal + MA; $P<0.05, P<0.01$, or $P<0.01$, respectively). Neither vehicle nor rottlerin significantly altered DAT expression in the absence of MA. Vehicle treatment did not alter MA-induced inhibition of DAT expression. Treatment with rottlerin significantly attenuated MA-induced inhibition of DAT expression ( $4 \mathrm{~h}$ post-MA: Veh + MA vs. $3.0 \mu \mathrm{g}$ rottlerin + MA; $P<0.05 ; 3 \mathrm{~d}$ and $14 \mathrm{~d}$ post-MA: 1.5 or $3.0 \mu \mathrm{g}$ rottlerin + MA; $P<0.05$ or $P<0.01$, respectively, Fig. 6A). MA-induced reduction in DAT expression was consistently less pronounced in $\mathrm{PKC} \delta(-/-)$ mice $[4 \mathrm{~h}, 3 \mathrm{~d}$, or $14 \mathrm{~d}$ post-MA: MAtreated PKC $\delta(+/+) v s$. MA-treated PKC $\delta(-/-) ; P<0.05, P<0.01$ or $P<0.01$, respectively; Fig. 6B]. The profile of the DAT results consistently paralleled that of the VMAT2 results (Fig. $6 \mathrm{C}$ and D).

\subsection{Effects of rottlerin on MA-induced increases in TUNEL-positive apoptotic cells in the striata of mice}

Earlier reports demonstrated that MA induces apoptotic cell death in striatal neurons. In the present study, we chose TUNEL staining (labeling by TUNEL marks the occurrence of DNA fragmentation, which occurs late in the apoptosis process) because some apoptosis was recognized to occur independently of caspase-3 activation, an early marker of apoptosis $[60,61]$. Unexpectedly, we failed to observe MA-induced TUNEL-positive cells in the striatum of PKC $\delta(+/+)$ mice. Few PKC $\delta(+/+)$ mice exhibited TUNEL-positive cells at 12 $\mathrm{h}, 1 \mathrm{~d}$, or $3 \mathrm{~d}$ after the final MA administration [i.e., four injections of $8 \mathrm{mg} / \mathrm{kg}$ MA, intraperitoneally (i.p.), at 2-h intervals or a single injection of MA (ranging from $20-40 \mathrm{mg}$ / $\mathrm{kg}$ )]. Thus, according to Zhu et al. [62, 63], we used 10-week-old male ICR mice (Taconic Farms, Inc., Samtako Bio Korea, O-San, South Korea). Because apoptotic cell death became detectable at a dose of $20 \mathrm{mg} / \mathrm{kg}$ of MA and reached a significant level at $35 \mathrm{mg} / \mathrm{kg}$ in our pilot study, a 35-mg/kg dose of MA was chosen for the present study. We also sacrificed animals $1 \mathrm{~d}$ after MA administration [62, 63]. Two animals out of 15 died within $1 \mathrm{~d}$ after receiving MA. Figure 7 shows representative photomicrographs of TUNEL-positive cells from the striatum of MA-treated mice with or without rottlerin. Weak TUNEL staining was observed in the absence of MA. Vehicle treatment did not significantly affect MA-induced TUNEL-positive cells. Treatment with MA resulted in a significant increase in TUNELpositive cells $(\mathrm{P}<0.01)$. No MA-treated animal died in the presence of rottlerin. Treatment with rottlerin significantly decreased TUNEL-positive cells dose-dependently (Veh + MA 
vs. 1.5 or $3.0 \mu \mathrm{g}$ rottlerin $+\mathrm{MA} ; P<0.05$ or $P<0.01$, respectively; $1.5 \mu \mathrm{g}$ rottlerin + MA vs. $3.0 \mu \mathrm{g}$ rottlerin $+\mathrm{MA} ; P<0.05$; Fig. 7).

\subsection{Effects of rottlerin on MA-induced oxidative stress in the striata of PKCס (+/+) mice: comparison with MA-treated PKCס (-/-) mice}

Figure 8 shows the changes in lipid peroxidation (as shown by 4-HNE expression and MDA level) and protein oxidation (as shown by protein carbonyl expression and protein carbonyl content). The levels of the lipid peroxidation and protein oxidation did not alter without MA treatment.

MDA and protein carbonyl content increased significantly in PKC $\delta(+/+)$ mice at $4 \mathrm{~h}$ after the final MA dose (both MDA and carbonyl; Sal + Sal vs. Sal + MA; $P<0.01$ ). These increases remained apparent 3 days later (both MDA and carbonyl; Sal + Sal vs. Sal + MA; $P<0.05)$. Pretreatment with rottlerin $(1.5$ or $3.0 \mu$ g, i.c.v.) significantly attenuated MAinduced oxidative stress in a dose-dependent manner (both time points in the levels of MDA and carbonyl; 4 h post-MA: Sal + MA vs. rottlerin 1.5 or $3.0 \mu \mathrm{g}+\mathrm{MA}, P<0.05$ or $P<0.01$, respectively; 3 days post-MA: Sal + MA vs. rottlerin 1.5 or $3.0 \mu \mathrm{g}+\mathrm{MA}, P<0.05$ or $P<$ $0.05)$. MA-induced increases in oxidative damage in the striatum were consistently less pronounced in PKC $\delta$ knockout mice [4 h post-MA: MA-treated $\mathrm{PKC} \delta(+/+) v s$. MA-treated PKC $\delta(-/-), P<0.01 ; 3$ days post-MA: MA-treated PKC $\delta(+/+) v s$. MA-treated PKC $\delta(-/-)$, $P<0.05]$. The attenuation of oxidative damage in rottlerin-treated $\mathrm{PKC} \delta(+/+)$ mice was comparable to that observed in knockout mice (Fig. 8A-D). Slot blot analyses were used to further evaluate the effects of MA on 4-HNE and protein carbonyl expression. MA-induced increases in the expression of these markers were attenuated by rottlerin treatment and in PKC $\delta(-/-)$ mice (Fig. 8E-H). Thus, the biochemical assessment of MDA and protein oxidation consistently paralleled our slot blot analysis of HNE and protein carbonyl content. Furthermore, both rottlerin and $\mathrm{PKC} \delta$ gene knockout attenuated ROS formation induced by MA (data not shown). All values of lipid peroxidation [as shown by 4-hydroxynonenal (4HNE) expression and the malondialdehyde level] and protein oxidation (as shown by protein carbonyl expression and protein carbonyl content) returned to near control levels $14 \mathrm{~d}$ after the final MA administration.

\section{Discussion}

The present study demonstrates that treatment with high doses of MA resulted in selective increases in $\mathrm{PKC} \delta$ expression in the striatum as compared with other isozymes, including $\mathrm{PKCa}, \beta \mathrm{I}, \beta \mathrm{II}$, or PKC $\zeta$. Genetic inhibition (gene knockout) of PKC $\delta$ or use of the pharmacological inhibitor of $\mathrm{PKC} \delta$ rottlerin significantly attenuated MA-induced increases in striatal DA turnover, behavioral impairments (as shown by reductions in locomotor activity and rota-rod performance), and decreases in striatal DA terminal markers (i.e., TH, DAT, and VMAT2). Moreover, PKC $\delta$ inhibition effectively blocks oxidative stress and apoptosis (as shown by TUNEL staining) induced by high doses of MA. Our results are highly significant in that they provide insight into the roles of oxidative stress and DA terminal loss in the poorly understood mechanism underlying MA-mediated neurodegeneration. Our findings also suggest that PKC $\delta$ may be an attractive target for the development of neuroprotective strategies against MA-induced DAergic degeneration.

Interestingly, in mice, the neurotoxic effect of MA appears to be specifically against the nigrostriatal DAergic system [51, 64, 65]. The influence of MA-induced neurochemical and histopathological changes on the motor behavior of animals has not yet been systemically studied, although we recently demonstrated MA-induced behavioral deficits in mice [39]. Because of similarities between the neuropathological profiles of high-dose MA treatment in rodents and Parkinson's disease in humans, it was hypothesized that neurotoxic doses of MA 
may lead to behavioral deficits in rodents. The present study showed that MA treatment significantly altered behavioral activity in wild-type mice, but not in rottlerin-treated or PKC $\delta$ knockout (-I-) mice. Several investigators have demonstrated a significant correlation between the reduction in behavioral activity and degree of striatal DA loss [39, 66, 67]. Typically, these studies demonstrated that pronounced impairments in behavioral responses occur after reducing the striatal DA content by $85 \%$ or more. In the present study, overt impairment of behavioral activity was noted after a reduction of only $68 \%$ in wild-type mice. Our data suggest that MA treatment produced a moderate behavioral deficit, although its intensity was less than that induced by treatment with 1-methyl-4-phenyl-1,2,3,6tetrahydropyridine (MPTP) [51, 65]. Thus, our results suggest that MA may be useful as a laboratory tool for modeling basal ganglia dysfunction in rodents and that overexpression of PKC $\delta$ may contribute to MA-induced behavioral deficits by an unknown mechanism.

Accumulating evidence has suggested that PKCs are sensitive targets for redox modification and functional alterations that mediate oxidant-induced cellular responses [24, 25, 68]. Similar to those studies, Nitti et al. [27] confirmed the relationship between PKC $\delta$ activation and ROS generation in an in vitro model. Domenicotti et al. [69] demonstrated that rottlerin acts as a free radical scavenger in glutathione-depleted neuroblastoma cells, protecting them from ROS-mediated apoptosis [69]. Nitti et al. [27] also demonstrated that rottlerin exerts protective effects comparable to those induced by a-tocoperol, counteracting apoptotic commitment and completely preventing alterations in the intracellular redox balance.

An earlier report demonstrated that DA-dependent oxidative stress may be the initial event in MA neurotoxicity [70]. DA oxidation has been implicated in MA toxicity by experiments showing that in vivo administration of antioxidants, such as ascorbate and vitamin E, inhibit MA-induced reduction in brain levels of DA [71]. DA auto-oxidation leads to the formation of reactive quinone derivatives, hydrogen peroxide, and free radicals $[72,73]$. Thus, intracellular DA-dependent oxidative stress may be sufficient to explain the selective MA toxicity for DA terminals.

DAergic signaling involves a delicate balance between DA release and re-uptake by the presynaptic nerve terminal. Normally, neuronal activation promotes vesicular release of DA into the synapse. DAT removes DA from the synapse and VMAT2 transports cytoplasmic DA into vesicles for storage, release, and protection from oxidation and reactive consequences. Accordingly, DAT and/or VMAT2 dysfunction may have neurotoxic consequences that result in damage to DAergic neurons [74]. Possible structural changes causing the present DAT effects may be the result of MA-induced ROS, because DATs are among the neuronal components that are especially susceptible to oxidative damage and ROS are formed after MA administration [75]. Increasing VMAT2 expression has been reported to reduce apoptosis after MA exposure and decreasing VMAT2 rendered cultured midbrain neurons more vulnerable to DAergic toxicity [76]. Additionally, increasing the expression of VMAT2 in vivo can mitigate the oxidative stress and gliosis caused by MA [77].

At $7 \mathrm{~d}$ after high doses of MA, Granado et al. [78] observed a significant decrease in DAT expression in mice, while another report [45] at the same time point demonstrated a significant decrease in VMAT2 expression in rats. In our study, DAT- and VMAT2expression remained lowered until $14 \mathrm{~d}$ after the final MA administration. PKC $\delta$ inhibition consistently and significantly attenuated the reductions in DAT and VMAT2 expression induced by MA. Although MA treatment produced an early stage of oxidative stress, ROS returned to near control levels 14 days later. Thus, these results may reflect an early stage of oxidative stress precipitating a cascade of events leading to PKC 8 -activated DA terminal damage following MA toxicity. However, the underlying mechanism remains to be 
determined, although we cannot exclude the possibility of certain positive effects modulated by astrocytic antioxidant potentials or unknown neurotrophic substances $[79,80]$.

In addition to its toxic effects on monoaminergic terminals, MA can also cause cell death via both apoptotic and necrotic mechanisms [8, 81-83]. In earlier work, brain regions were evaluated for the presence of cytoskeletal structural protein proteolysis as markers for necrotic and apoptotic cell death after MA injections [84]. Significant increases were observed in the breakdown product levels of aII-spectrin and MAP- $\tau$, which are thought to indicate neuronal cell death processes $[85,86]$. These breakdown products suggest that MA causes activation of pro-apoptotic caspase-3 and pro-necrotic calpain-1 [10, 84].

Several studies have demonstrated the induction of TUNEL-positive apoptotic cells in the cortex and striatum of rodents by MA [62, 87-91]. A previous study demonstrated that MAinduced apoptosis (TUNEL) peaks at $24 \mathrm{~h}$, while we showed here that depletion of DA terminal markers (TH, DAT, and VMAT2) was more pronounced at $3 \mathrm{~d}$ after the final MA administration; that is, MA-induced apoptosis (and oxidative stress) precedes DA terminal toxicities. It is well recognized that reactive oxygen species directly modulate PKC $\delta$ activity and that caspase-3-dependent proteolytic activation of PKC $\delta$ mediates as well as regulates apoptotic cell death in DAergic cells. Thus, a positive feedback amplification loop exists between PKC $\delta$-mediated oxidative/apoptotic responses and altered circumstances of the DA terminal, which may enhance DAergic toxicity induced by MA. Conversely, as demonstrated by others [83], we observed in some cases (data not shown) the peak of MAinduced apoptosis of some striatal neurons at $3 \mathrm{~d}$ after MA administration. One plausible explanation for this discrepancy may be related to age, the species of mice, as well as MA doses [63].

Several reports have suggested a direct correlation between MA-induced hyperthermia and the severity of DAergic neurotoxicity in mice [92-94]. Similarly, our recent report showed that $\mathrm{PKC} \delta$ activation may be, at least in part, a factor in MA-induced hyperthermia [9]. However, pretreatment with reserpine, a drug known to produce hypothermia, does not prevent MA-induced neurotoxicity [95, 96]. Moreover, reserpine-stimulated elevations in striatal cytoplasmic DA levels produce an increase in cytoplasmic levels of highly reactive 5-S- cysteinyldopamine, a product of DA oxidation [97], and potentiate MA-induced dopaminergic degeneration [96], suggesting that hyperthermia cannot be the sole mediator of MA toxicity, and that factors other than thermal responses can contribute to its neurotoxic effects [98].

Similar to our data, Zhang et al. [99] provided evidence that rottlerin treatment rescues $\mathrm{TH}^{+}$ neurons from 1-methyl-4-phenylpyridinium $\left(\mathrm{MPP}^{+}\right)$-induced neurotoxicity in vitro. Further studies in animal models revealed that rottlerin effectively attenuates MPTP-induced increases in PKC $\delta$ kinase activity in mice. Furthermore, rottlerin administration $(20 \mathrm{mg} / \mathrm{kg}$, p.o.) attenuated neurochemical depletion and locomotor activity in MPTP-treated animals, demonstrating protection against both behavioral and neurochemical deficits. Rottlerin treatment $(20 \mathrm{mg} / \mathrm{kg}$, p.o.) also protected against MPTP-induced nigral loss of TH neurons, revealing a neuroprotective effect. These results are, at least in part, in line with ours, reflecting a role for PKC $\delta$ in MA-induced dopaminergic toxicity, although it is acknowledged that pharmacological differences may exist with regard to DAergic toxicity caused by MPTP $v s$. MA $[51,65,100]$.

Although many earlier studies have used rottlerin as a PKC $\delta$-selective inhibitor [23, 99, 101-104], recent studies have demonstrated that rottlerin might not act directly on PKC $\delta$, but rather induce cellular changes that mimic those produced by the direct inhibition of PKC $\delta$ [105-107]. However, the effects of rottlerin were comparable to those of PKC $\delta$ gene 
knockout in our study. Thus, it is possible that rottlerin mimicked the inhibition of PKC $\delta$ activity in our experimental circumstances. However, the additional neuropharmacological effects of rottlerin remain to be elucidated.

In conclusion, we suggest that MA-induced $\mathrm{PKC} \delta$ overexpression impairs the striatal dopaminergic system as well as behavioral activity, and that genetic or pharmacological inhibition of PKC $\delta$ blocks oxidative stresses (i.e., lipid peroxidation and protein oxidation), apoptosis and DA terminal damage induced by MA. Finally, we propose that genetic depletion or pharmacological inhibition of PKC $\delta$ may offer novel therapeutic strategies against striatal toxicity induced by DAergic neurotoxins such as MA.

\section{Acknowledgments}

This study was supported by a grant (\#2011K000271) from the Brain Research Center from $21^{\text {st }}$ Century Frontier Research Program funded by the Ministry of Science and Technology, Republic of Korea. This work was, in part, supported by grants from Ministry of Health Labour and Welfare (MHLW):Research on Risk of Chemical Substances, and Ministry of Education, Culture, Sports, Science and Technology (MEST): Academic Frontier Project. Xuan-Khanh Thi Nguyen and Jae-Hyung Bach were supported by BK 21 program. Equipment at the Institute of Pharmaceutical Science (Kangwon National University) was used for this study.

\section{References}

1. Krasnova IN, Cadet JL. Methamphetamine toxicity and messengers of death. Brain Res Rev. 2009; 60:379-407. [PubMed: 19328213]

2. United Nations Office on Drugs and Crime. World drug report. United Nations Office on Drugs and Crime; Analysis. Vienna: 2007.

3. Albertson TE, Derlet RW, Van Hoozen BE. Methamphetamine and the expanding complications of amphetamines. West J Med. 1999; 170:214-9. [PubMed: 10344175]

4. Scott JC, Woods SP, Matt GE, Meyer RA, Heaton RK, Atkinson JH, Grant I. Neurocognitive effects of methamphetamine: a critical review and meta-analysis. Neuropsychol Rev. 2007; 17:275-97. [PubMed: 17694436]

5. Darke S, Kaye S, McKetin R, Duflou J. Major physical and psychological harms of methamphetamine use. Drug Alcohol Rev. 2008; 27:253-62. [PubMed: 18368606]

6. Perez JA Jr. Arsura EL, Strategos S. Methamphetamine-related stroke: four cases. J Emerg Med. 1999; 17:469-71. [PubMed: 10338241]

7. Kim HC, Jhoo WK, Choi DY, Im DH, Shin EJ, Suh JH, Floyd RA, Bing G. Protection of methamphetamine nigrostriatal toxicity by dietary selenium. Brain Res. 1999; 851:76-86. [PubMed: 10642830]

8. Davidson C, Gow AJ, Lee TH, Ellinwood EH. Methamphetamine neurotoxicity: Necrotic and apoptotic mechanisms and relevance to human abuse and treatment. Brain Res. 2001; 36:1-22.

9. Shin EJ, Duong CX, Nguyen TX, Bing G, Bach JH, Park DH, Nakayama K, Ali SF, Kanthasamy AG, Cadet JL, Nabeshima T, Kim HC. PKC $\delta$ inhibition enhances tyrosine hydroxylase phosphorylation in mice after methamphetamine treatment. Neurochem Int. 2011; 59:39-50. [PubMed: 21672585]

10. Gold MS, Kobeissy FH, Wang KK, Merlo LJ, Bruijnzeel AW, Krasnova IN, Cadet JL. Methamphetamine- and trauma-induced brain injuries: comparative cellular and molecular neurobiological substrates. Biol Psychiatry. 2009; 66:118-27. [PubMed: 19345341]

11. Cadet JL, Krasnova IN, Ladenheim B, Cai NS, McCoy MT, Atianjoh FE. Methamphetamine preconditioning: differential protective effects on monoaminergic systems in the rat brain. Neurotox Res. 2009; 15:252-9. [PubMed: 19384598]

12. Thomas DM, Walker PD, Benjamins JA, Geddes TJ, Kuhn DM. Methamphetamine neurotoxicity in dopamine nerve endings of the striatum is associated with microglial activation. $\mathrm{J}$ Pharmacol Exp Ther. 2004; 311:1-7. [PubMed: 15163680]

13. Cadet JL, Krasnova IN, Jayanthi S, Lyles J. Neurotoxicity of substituted amphetamines: molecular and cellular mechanisms. Neurotox Res. 2007; 11:183-202. [PubMed: 17449459] 
14. Kitamura O, Tokunaga I, Gotohda T, Kubo S. Immunohistochemical investigation of dopaminergic terminal markers and caspase- 3 activation in the striatum of human methamphetamine users. Int J Legal Med. 2007; 121:163-8. [PubMed: 16622715]

15. Moszczynska A, Fitzmaurice P, Ang L, Kalasinsky KS, Schmunk GA, Peretti FJ, Aiken SS, Wickham DJ, Kish SJ. Why is parkinsonism not a feature of human methamphetamine users? Brain. 2004; 127:363-70. [PubMed: 14645148]

16. Wilson JM, Kalasinsky KS, Levey AI, Bergeron C, Reiber G, Anthony RM, Schmunk GA, Shannak K, Kish SJ. Striatal dopamine nerve terminal markers in human, chronic methamphetamine users. Nat Med. 1996; 2:699-703. [PubMed: 8640565]

17. LaVoie MJ, Hastings TG. Dopamine quinone formation and protein modification associated with the striatal neurotoxicity of methamphetamine: evidence against a role for extracellular dopamine. J Neurosci. 1999; 19:1484-91. [PubMed: 9952424]

18. Gluck MR, Moy LY, Jayatilleke E, Hogan KA, Manzino L, Sonsalla PK. Parallel increases in lipid and protein oxidative markers in several mouse brain regions after methamphetamine treatment. $\mathrm{J}$ Neurochem. 2001; 79:152-60. [PubMed: 11595767]

19. Jayanthi S, Ladenheim B, Cadet JL. Methamphetamine-induced changes in antioxidant enzymes and lipid peroxidation in copper/zinc-superoxide dismutase transgenic mice. Ann N Y Acad Sci. 1998; 844:92-102. [PubMed: 9668667]

20. Kobeissy FH, Warren MW, Ottens AK, Sadasivan S, Zhang Z, Gold MS, Wang KK. Psychoproteomic analysis of rat cortex following acute methamphetamine exposure. J Proteome Res. 2008; 7:1971-83. [PubMed: 18452277]

21. Li X, Wang H, Qiu P, Luo H. Proteomic profiling of proteins associated with methamphetamineinduced neurotoxicity in different regions of rat brain. Neurochem Int. 2008; 52:256-64. [PubMed: 17904249]

22. Dempsey EC, Newton AC, Mochly-Rosen D, Fields AP, Reyland ME, Insel PA, Messing RO. Protein kinase $\mathrm{C}$ isozymes and the regulation of diverse cell responses. Am J Physiol Lung Cell Mol Physiol. 2000; 279:L429-38. [PubMed: 10956616]

23. Gschwendt M. Protein kinase C delta. Eur J Biochem. 1999; 259:555-64. [PubMed: 10092837]

24. Gopalakrishna R, Gundimeda U. Protein kinase C as a molecular target for cancer prevention by selenocompounds. Nutr Cancer. 2001; 40:55-63. [PubMed: 11799924]

25. Gopalakrishna R, Jaken S. Protein kinase C signaling and oxidative stress. Free Radic Biol Med. 2000; 28:1349-61. [PubMed: 10924854]

26. Chiarpotto E, Domenicotti C, Paola D, Vitali A, Nitti M, Pronzato MA, Biasi F, Cottalasso D, Marinari UM, Dragonetti A, Cesaro P, Isidoro C, Poli G. Regulation of rat hepatocyte protein kinase $\mathrm{C}$ beta isoenzymes by the lipid peroxidation product 4-hydroxy-2,3-nonenal: A signaling pathway to modulate vesicular transport of glycoproteins. Hepatology. 1999; 29:1565-72. [PubMed: 10216144]

27. Nitti M, d'Abramo C, Traverso N, Verzola D, Garibotto G, Poggi A, Odetti P, Cottalasso D, Marinari UM, Pronzato MA, Domenicotti C. Central role of PKCdelta in glycoxidation-dependent apoptosis of human neurons. Free Radic Biol Med. 2005; 38:846-56. [PubMed: 15749380]

28. Domenicotti C, Paola D, Vitali A, Nitti M, d'Abramo C, Cottalasso D, Maloberti G, Biasi F, Poli G, Chiarpotto E, Marinari UM, Pronzato MA. Glutathione depletion induces apoptosis of rat hepatocytes through activation of protein kinase $\mathrm{C}$ novel isoforms and dependent increase in AP-1 nuclear binding. Free Radic Biol Med. 2000; 29:1280-90. [PubMed: 11118818]

29. Pubill D, Chipana C, Camins A, Pallas M, Camarasa J, Escubedo E. Free radical production induced by methamphetamine in rat striatal synaptosomes. Toxicol Appl Pharmacol. 2005; 204:57-68. [PubMed: 15781294]

30. Cowell RM, Kantor L, Hewlett GH, Frey KA, Gnegy ME. Dopamine transporter antagonists block phorbol ester-induced dopamine release and dopamine transporter phosphorylation in striatal synaptosomes. Eur J Pharmacol. 2000; 389:59-65. [PubMed: 10686296]

31. Kantor L, Gnegy ME. Protein kinase C inhibitors block amphetamine-mediated dopamine release in rat striatal slices. J Pharmacol Exp Ther. 1998; 284:592-8. [PubMed: 9454802]

32. Kantor L, Hewlett GH, Park YH, Richardson-Burns SM, Mellon MJ, Gnegy ME. Protein kinase C and intracellular calcium are required for amphetamine-mediated dopamine release via the 
norepinephrine transporter in undifferentiated PC12 cells. J Pharmacol Exp Ther. 2001; 297:101624. [PubMed: 11356924]

33. Miyamoto A, Nakayama K, Imaki H, Hirose S, Jiang Y, Abe M, Tsukiyama T, Nagahama H, Ohno S, Hatakeyama S, Nakayama KI. Increased proliferation of B cells and auto-immunity in mice lacking protein kinase Cdelta. Nature. 2002; 416:865-9. [PubMed: 11976687]

34. Franklin, KBJ.; Paxinos, G. The Mouse Brain in Stereotaxic Coordinates. 3rd ed.. Academic Press; San Diego: 2008.

35. Shin EJ, Chae JS, Park SJ, Kim SC, Koo KH, Yamada K, Nabeshima T, Kim HC. Growth hormone-releaser diet attenuates beta-amyloid(1-42)-induced cognitive impairment via stimulation of the insulin-like growth factor (IGF)-1 receptor in mice. J Pharmacol Sci. 2009; 109:139-43. [PubMed: 19151546]

36. Smith FL, Gabra BH, Smith PA, Redwood MC, Dewey WL. Determination of the role of conventional, novel and atypical PKC isoforms in the expression of morphine tolerance in mice. Pain. 2007; 127:129-39. [PubMed: 16965856]

37. Smith FL, Javed RR, Smith PA, Dewey WL, Gabra BH. PKC and PKA inhibitors reinstate morphine-induced behaviors in morphine tolerant mice. Pharmacol Res. 2006; 54:474-80. [PubMed: 17056270]

38. Shin EJ, Nguyen TXK, Nguyen TPK, Mai AT, Park SJ, Bach JH, Park DH, Kim HC. Attenuation of Methamphetamine-Induced Nigrostriatal Dopaminergic Toxicity by Pharmacological and Genetic Inhibition of Protein Kinase C $\delta$. Spring International Convention of the Pharmaceutical Society of Korea. Daegu EXCO: Pharmaceutical Society of Korea. 2010:P1-96.

39. Jung BD, Shin EJ, Nguyen XK, Jin CH, Bach JH, Park SJ, Nah SY, Wie MB, Bing G, Kim HC. Potentiation of methamphetamine neurotoxicity by intrastriatal lipopolysaccharide administration. Neurochem Int. 2010; 56:229-44. [PubMed: 19850096]

40. Choi DY, Liu M, Hunter RL, Cass WA, Pandya JD, Sullivan PG, Shin EJ, Kim HC, Gash DM, Bing G. Striatal neuroinflammation promotes Parkinsonism in rats. PLoS One. 2009; 4:e5482. [PubMed: 19424495]

41. Hunter RL, Dragicevic N, Seifert K, Choi DY, Liu M, Kim HC, Cass WA, Sullivan PG, Bing G. Inflammation induces mitochondrial dysfunction and dopaminergic neurodegeneration in the nigrostriatal system. J Neurochem. 2007; 100:1375-86. [PubMed: 17254027]

42. Li Z, Choi DY, Shin EJ, Hunter RL, Jin CH, Wie MB, Kim MS, Park SJ, Bing G, Kim HC. Phenidone protects the nigral dopaminergic neurons from LPS-induced neurotoxicity. Neurosci Lett. 2008; 445:1-6. [PubMed: 18760329]

43. Liu M, Hunter R, Nguyen XV, Kim HC, Bing G. Microsomal epoxide hydrolase deletion enhances tyrosine hydroxylase phosphorylation in mice after MPTP treatment. J Neurosci Res. 2008; 86:2792-801. [PubMed: 18500758]

44. Kwon YS, Ann HS, Nabeshima T, Shin EJ, Kim WK, Jhoo JH, Jhoo WK, Wie MB, Kim YS, Jang KJ, Kim HC. Selegiline potentiates the effects of EGb 761 in response to ischemic brain injury. Neurochem Int. 2004; 45:157-70. [PubMed: 15082233]

45. Eyerman DJ, Yamaoto BK. A rapid oxidation and persistent decrease in the vesicular monoamine transporter 2 after methamphetamine. J Neurochem. 2007; 103:1219-27. [PubMed: 17683483]

46. Nguyen XV, Liu M, Kim HC, Bing G. Effects of prodynorphin deletion on striatal dopamine in mice during normal aging and in response to MPTP. Exp Neurol. 2009; 219:228-38. [PubMed: 19500577]

47. Liu M, Choi DY, Hunter RL, Pandya JD, Cass WA, Sullivan PG, Kim HC, Gash DM, Bing G. Trichloroethylene induces dopaminergic neurodegeneration in Fisher 344 rats. J Neurochem. 2010; 112:773-83. [PubMed: 19922440]

48. Nakajima A, Yamada K, Nagai T, Uchiyama T, Miyamoto Y, Mamiya T, He J, Nitta A, Mizuno M, Tran MH, Seto A, Yoshimura M, Kitaichi K, Hasegawa T, Saito K, Yamada K, Seishima M, Sekikawa K, Kim HC, Nabeshima T. Role of tumor necrosis factor-alpha in methamphetamineinduced drug dependence and neurotoxicity. J Neurosci. 2004; 24:2212-25. [PubMed: 14999072]

49. Nagatsu T, Oka K, Kato T. Highly sensitive assay for tyrosine hydroxylase activity by highperformance liquid chromatography. J Chromatogr. 1979; 163:247-52. [PubMed: 44298] 
50. Jareno EJ, Bosch-Morell F, Fernandez-Delgado R, Donat J, Romero FJ. Serum malondialdehyde in HIV seropositive children. Free Radic Biol Med. 1998; 24:503-6. [PubMed: 9438563]

51. Kim HC, Jhoo WK, Shin EJ, Bing G. Selenium deficiency potentiates methamphetamine-induced nigral neuronal loss; comparison with MPTP model. Brain Res. 2000; 862:247-52. [PubMed: 10799693]

52. Oliver CN, Ahn BW, Moerman EJ, Goldstein S, Stadtman ER. Age-related changes in oxidized proteins. J Biol Chem. 1987; 262:5488-91. [PubMed: 3571220]

53. Benedetti A, Comporti M, Esterbauer H. Identification of 4-hydroxynonenal as a cytotoxic product originating from the peroxidation of liver microsomal lipids. Biochim Biophys Acta. 1980; 620:281-96. [PubMed: 6254573]

54. Tran HY, Shin EJ, Saito K, Nguyen XK, Chung YH, Jeong JH, Bach JH, Park DH, Yamada K, Nabeshima T, Yoneda Y, Kim HC. Protective potential of IL-6 against trimethyltin-induced neurotoxicity in vivo. Free Radic Biol Med. 2012; 52:1159-74. [PubMed: 22245015]

55. Giambalvo CT. Protein kinase $\mathrm{C}$ and dopamine release--II. Effect of dopamine acting drugs in vivo. Biochem Pharmacol. 1988; 37:4009-17. [PubMed: 3056415]

56. Giambalvo CT. Protein kinase $\mathrm{C}$ and dopamine release--III. Effect of dopamine depleting drugs. Biochem Pharmacol. 1989; 38:4445-54. [PubMed: 2574975]

57. Fornai F, Battaglia G, Gesi M, Orzi F, Nicoletti F, Ruggieri S. Dose-dependent protective effects of apomorphine against methamphetamine-induced nigrostriatal damage. Brain Res. 2001; 898:27-35. [PubMed: 11292446]

58. Wilson JM, Kalasinski KS, Levey AI, Bergeron C, Reiber G, Anthony RT, Schmunk GA, Shannak K, Haycock JW, Kish SJ. Striatal dopamine nerve terminal markers in human, chronic methamphetamine users. Nat Med. 1996; 2:699-703. [PubMed: 8640565]

59. Fumagalli F, Gainetdinov RR, Valenzano KJ, Caron MG. Role of dopamine transporter in methamphetamine-induced neurotoxicity: evidence from mice lacking the transporter. J Neurosci. 1998; 18:4861-9. [PubMed: 9634552]

60. Ferrer I, Friguls B, Dalfó E, Justicia C, Planas AM. Caspase-dependent and caspase-independent signalling of apoptosis in the penumbra following middle cerebral artery occlusion in the adult rat. Neuropathol Appl Neurobiol. 2003; 29:472-81. [PubMed: 14507339]

61. Spalding KL, Dharmarajan AM, Harvey AR. Caspase-independent retinal ganglion cell death after target ablation in the neonatal rat. Eur J Neurosci. 2005; 21:33-45. [PubMed: 15654841]

62. Zhu JP, Xu W, Angulo JA. Methamphetamine-induced cell death: selective vulnerability in neuronal subpopulations of the striatum in mice. Neuroscience. 2006; 140:607-22. [PubMed: 16650608]

63. Zhu JP, Xu W, Angulo JA. Disparity in the temporal appearance of methamphetamine-induced apoptosis and depletion of dopamine terminal markers in the striatum of mice. Brain Res. 2005; 1049:171-81. [PubMed: 16043139]

64. Conricode KM, Brewer KA, Exton JH. Activation of phospholipase D by protein kinase C. Evidence for a phosphorylation-independent mechanism. J Biol Chem. 1992; 267:7199-202. [PubMed: 1559964]

65. Gerlach M, Riederer P. Animal models of Parkinson's disease: an empirical comparison with the phenomenology of the disease in man. J Neural Transm. 1996; 103:987-1041. [PubMed: 9013391]

66. Lenard LG, Beer B. Relationship of brain levels of norepinephrine and dopamine to avoidance behavior in rats after intraventricular administration of 6-hydoxydopamine. Pharmacol Biochem Behav. 1975; 3:895-9. [PubMed: 1208632]

67. Neill DB, Boggan WO, Grossman SP. Impairment of avoidance performance by intrastriatal administration of 6-hydroxydopamine. Pharmacol Biochem Behav. 1974; 2:97-103. [PubMed: 4597522]

68. Kanthasamy A, Jin H, Mehrotra S, Mishra R, Kanthasamy A, Rana A. Novel cell death signaling pathways in neurotoxicity models of dopaminergic degeneration: Relevance to oxidative stress and neuroinflammation in Parkinson's disease. NeuroToxicology. 2010; 31:555-561. [PubMed: 20005250] 
69. Domenicotti C, Marengo B, Verzola D, Garibotto G, Traverso N, Patriarca S, Maloberti G, Cottalasso D, Poli G, Passalacqua M, Melloni E, Pronzato MA, Marinari UM. Role of PKC-delta activity in glutathione-depleted neuroblastoma cells. Free Radic Biol Med. 2003; 35:504-16. [PubMed: 12927600]

70. Cubells JF, Rayport S, Rajendran G, Sulzer D. Methamphetamine neurotoxicity involves vacuolation of endocytic organelles and dopamine-dependent intracellular oxidative stress. J Neurosci. 1994; 14:2260-71. [PubMed: 8158268]

71. De Vito MJ, Wagner GC. Methamphetamine-induced neuronal damage: a possible role for free radicals. Neuropharmacology. 1989; 28:1145-50. [PubMed: 2554183]

72. Graham DG, Tiffany SM, Bell WR Jr. Gutknecht WF. Autoxidation versus covalent binding of quinones as the mechanism of toxicity of dopamine, 6-hydroxydopamine, and related compounds toward C1300 neuroblastoma cells in vitro. Mol Pharmacol. 1978; 14:644-53. [PubMed: 567274]

73. Slivka A, Cohen G. Hydroxyl radical attack on dopamine. J Biol Chem. 1985; 260:15466-72. [PubMed: 2999117]

74. Riddle EL, Fleckenstein AE, Hanson GR. Role of monoamine transporters in mediating psychostimulant effects. AAPS J. 2005; 7:E847-51. [PubMed: 16594636]

75. Fleckenstein AE, Metzger RR, Wilkins DG, Gibb JW, Hanson GR. Rapid and reversible effects of methamphetamine on dopamine transporters. J Pharmacol Exp Ther. 1997; 282:834-8. [PubMed: 9262348]

76. Vergo S, Johansen JL, Leist M, Lotharius J. Vesicular monoamine transporter 2 regulates the sensitivity of rat dopaminergic neurons to disturbed cytosolic dopamine levels. Brain Res. 2007; 1185:18-32. [PubMed: 18028884]

77. Guillot TS, Richardson JR, Wang MZ, Li YJ, Taylor TN, Ciliax BJ, Zachrisson O, Mercer A, Miller GW. PACAP38 increases vesicular monoamine transporter 2 (VMAT2) expression and attenuates methamphetamine toxicity. Neuropeptides. 2008; 42:423-34. [PubMed: 18533255]

78. Granado N, Lastres-Becker I, Ares-Santos S, Oliva I, Martin E, Cuadrado A, Moratalla R. Nrf2 deficiency potentiates methamphetamine-induced dopaminergic axonal damage and gliosis in the striatum. Glia. 2011; 59:1850-63. [PubMed: 21882243]

79. Miyazaki I, Asanuma M, Kikkawa Y, Takeshima M, Murakami S, Miyoshi K, Sogawa N, Kita T. Astrocyte-derived metallothionein protects dopaminergic neurons from dopamine quinone toxicity. Glia. 2011; 59:435-51. [PubMed: 21264950]

80. Zhang W, Shin EJ, Wang T, Lee PH, Pang H, Wie MB, Kim WK, Kim SJ, Huang WH, Wang Y, Zhang W, Hong JS, Kim HC. 3-Hydroxymorphinan, a metabolite of dextromethorphan, protects nigrostriatal pathway against MPTP-elicited damage both in vivo and in vitro. FASEB J. 2006; 20:2496-511. [PubMed: 17142799]

81. Cadet JL, Krasnova IN, Jayanthi S, Lyles J. Neurotoxicity of substituted amphetamines: Molecular and cellular mechanisms. Neurotoxicity Res. 2007; 11:183-202.

82. Deng X, Cai NS, McCoy MT, Chen W, Trush MA, Cadet JL. Methamphetamine induces apoptosis in an immortalized rat striatal cell line by activating the mitochondrial cell death pathway. Neuropharmacology. 2002; 42:837-45. [PubMed: 12015210]

83. Jayanthi S, Deng X, Noailles PA, Ladenheim B, Cadet JL. Methamphetamine induces neuronal apoptosis via cross-talks between endoplasmic reticulum and mitochondria-dependent death cascades. FASEB J. 2004; 18:238-51. [PubMed: 14769818]

84. Warren MW, Kobeissy FH, Liu MC, Hayes RL, Gold MS, Wang KK. Concurrent calpain and caspase- 3 mediated proteolysis of alpha II-spectrin and tau in rat brain after methamphetamine exposure: A similar profile to traumatic brain injury. Life Sci. 2005; 78:301-9. [PubMed: 16125733]

85. Wallace TL, Vorhees CV, Zemlan FP, Gudelsky GA. Methamphetamine enhances the cleavage of the cytoskeletal protein tau in the rat brain. Neuroscience. 2003; 116:1063-8. [PubMed: 12617947]

86. Nath R, Raser KJ, Stafford D, Hajimohammadreza I, Posner A, Allen H, Talanian RV, Yuen P, Gilbertsen RB, Wang KK. Non-erythroid alpha-spectrin breakdown by calpain and interleukin 1 beta-converting-enzyme-like protease(s) in apoptotic cells: contributory roles of both protease families in neuronal apoptosis. Biochem J. 1996; 319:683-90. [PubMed: 8920967] 
87. Stumm G, Schlegel J, Schafer T, Wurz C, Mennel HD, Krieg JC, Vedder H. Amphetamines induce apoptosis and regulation of bcl-x splice variants in neocortical neurons. FASEB J. 1999; 13:106572. [PubMed: 10336889]

88. Deng X, Cadet JL. Methamphetamine-induced apoptosis is attenuated in the striata of copper-zinc superoxide dismutase transgenic mice. Brain Res Mol Brain Res. 2000; 83:121-4. [PubMed: 11072101]

89. Deng X, Wang Y, Chou J, Cadet JL. Methamphetamine causes widespread apoptosis in the mouse brain: evidence from using an improved TUNEL histochemical method. Brain Res Mol Brain Res. 2001; 93:64-9. [PubMed: 11532339]

90. Cadet JL, Jayanthi S, Deng X. Speed kills: cellular and molecular bases of methamphetamineinduced nerve terminal degeneration and neuronal apoptosis. FASEB J. 2003; 17:1775-88. [PubMed: 14519657]

91. Loonam TM, Noailles PA, Yu J, Zhu JP, Angulo JA. Substance P and cholecystokinin regulate neurochemical responses to cocaine and methamphetamine in the striatum. Life Sci. 2003; 73:727-39. [PubMed: 12801594]

92. Bowyer JF, Tank AW, Newport GD, Slikker W Jr, Ali SF, Holson RR. The influence of environmental temperature on the transient effects of methamphetamine on dopamine levels and dopamine release in striatum. J Pharmacol Exp Ther. 1992; 260:817-24. [PubMed: 1346646]

93. Bowyer JF, Davies DL, Schmued L, Broening HW, Newport GD, Slikker W Jr, Holson RR. Further studies of the role of hyperthermia in methamphetamine neurotoxicity. J Pharmacol Exp Ther. 1994; 268:1571-80. [PubMed: 8138969]

94. Albers DS, Sonsalla PK. Methamphetamine-induced hyperthermia and dopaminergic neurotoxicity in mice: pharmacological profile of protective and nonprotective agents. J Pharmacol Exp Ther. 1995; 275:1104-14. [PubMed: 8531070]

95. Ricaurte GA, Fuller RW, Perry KW, Seiden LS, Schuster CR. Fluoxetine increases long-lasting neostriatal dopamine depletion after administration of D-methamphetamine and D-amphetamine. Neuropharmacology. 1983; 22:1165-9. [PubMed: 6606137]

96. Wagner GC, Lucot JB, Schuster CR, Seiden LS. a-Methyltyrosine attenuates and reserpine increases methamphetamine-induced neuronal changes. Brain Res. 1983; 270:285-8. [PubMed: 6883096]

97. Fornstedt B, Carlsson A. A marked rise in 5-S-cysteinyl-dopamine levels in guinea pig striatum following reserpine treatment. J Neural Transm. 198976:155-61. [PubMed: 2496196]

98. Fumagalli F, Gainetdinov RR, Wang YM, Valenzano KJ, Miller GW, Caron MG. Increased methamphetamine neurotoxicity in heterozygous vesicular monoamine transporter 2 knock-out mice. J Neurosci. 1999; 19:2424-31. [PubMed: 10087057]

99. Zhang D, Anantharam V, Kanthasamy A, Kanthasamy AG. Neuroprotective effect of protein kinase $\mathrm{C}$ delta inhibitor rottlerin in cell culture and animal models of Parkinson's disease. $\mathrm{J}$ Pharmacol Exp Ther. 2007; 322:913-22. [PubMed: 17565007]

100. Bourque M, Dluzen DE, Di Paolo T. Neuroprotective actions of sex steroids in Parkinson's disease. Front Neuroendocrinol. 2009; 30:142-57. [PubMed: 19410597]

101. Gschwendt M, Muller HJ, Kielbassa K, Zang R, Kittstein W, Rincke G, Markis F. Rottlerin, a novel protein kinase inhibitor. Biochem Biophys Res Commun. 1994; 199:93-8. [PubMed: 8123051]

102. Li C, Chen X, Williams JA. Regulation of CCK-induced amylase release by PKC-delta in rat pancreatic acinar cells. Am J Physiol Gastrointest Liver Physiol. 2004; 287:G764-71. [PubMed: 15217780]

103. Yokoyama G, Fujii T, Tayama K, Yamana H, Kuwano M, Shirouzu K. PKCdelta and MAPK mediate G(1) arrest induced by PMA in SKBR-3 breast cancer cells. Biochem Biophys Res Commun. 2005; 327:720-6. [PubMed: 15649406]

104. Zhang D, Kanthasamy A, Yang Y, Anantharam V. Protein kinase C delta negatively regulates tyrosine hydroxylase activity and dopamine synthesis by enhancing protein phosphatase-2A activity in dopaminergic neurons. J Neurosci. 2007; 27:5349-62. [PubMed: 17507557]

105. Soltoff SP. Rottlerin: an inappropriate and ineffective inhibitor of PKCdelta. Trends Pharmacol Sci. 2007; 28:453-8. [PubMed: 17692392] 
106. Susarla BT, Robinson MB. Rottlerin, an inhibitor of protein kinase Cdelta (PKCdelta), inhibits astrocytic glutamate transport activity and reduces GLAST immunoreactivity by a mechanism that appears to be PKCdelta-independent. J Neurochem. 2003; 86:635-45. [PubMed: 12859677]

107. Tapia JA, Jensen RT, Garcia-Marin LJ. Rottlerin inhibits stimulated enzymatic secretion and several intracellular signaling transduction pathways in pancreatic acinar cells by a non-PKCdelta-dependent mechanism. Biochim Biophys Acta. 2006; 1763:25-38. [PubMed: 16364465] 


\section{A. Treatment with inhibitors of PKC $\alpha \& \beta, \beta, \zeta$ or $\delta$}

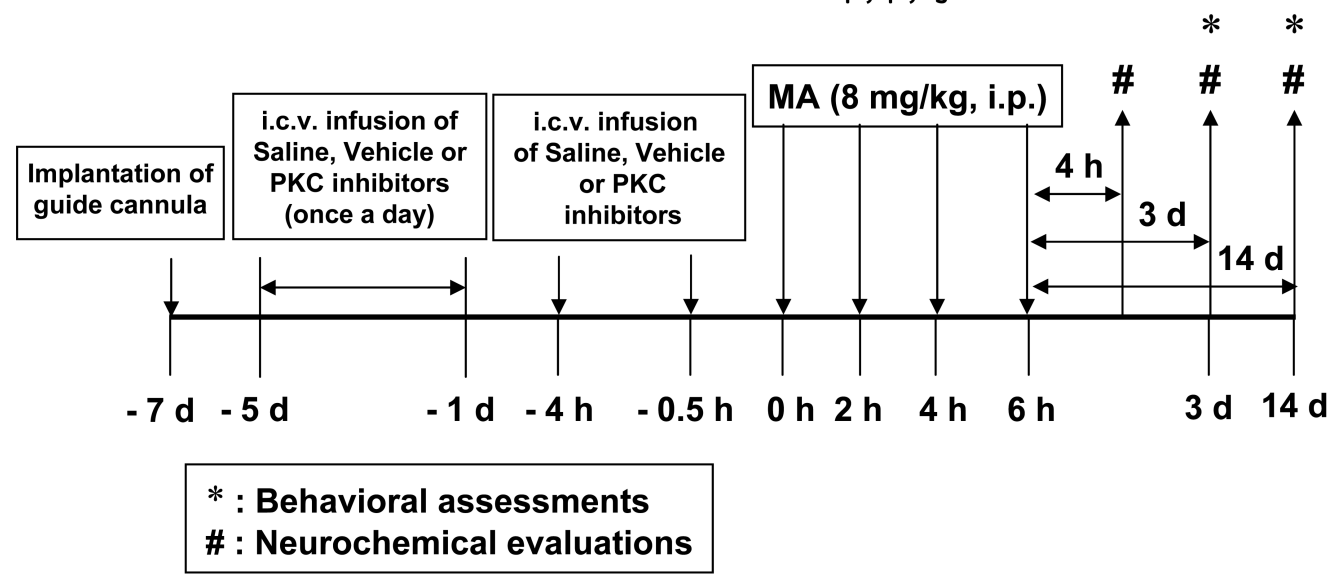

B. $\operatorname{PKC} \delta(-/-)$

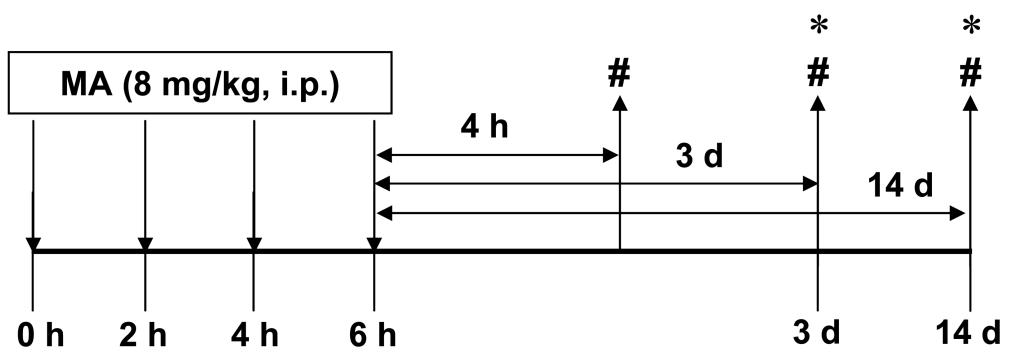

\section{* : Behavioral assessments \\ \# : Neurochemical evaluations}

\section{Experimental schedule for TUNEL staining}

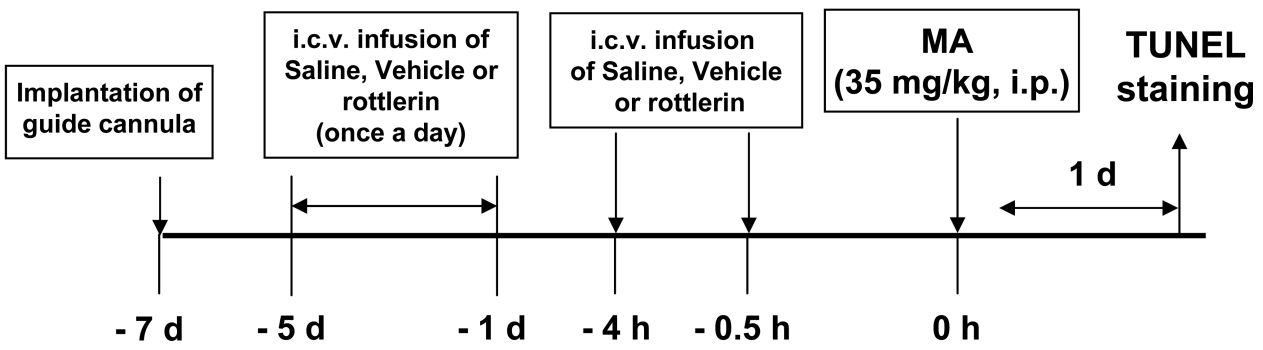

Fig. 1.

Experimental schedule to evaluate the effect of PKC inhibitors (A) or $P K C \delta$ gene knockout (B) on dopaminergic toxicity induced by methamphetamine (MA) in mice and to evaluate the effect of rottlerin, a PKC $\delta$ inhibitor $(\mathbf{C})$, on apoptosis induced by MA. PKC $\delta(+/+)$ or PKC $\delta(-/-)$ mice received four injections of MA hydrochloride [8 $\mathrm{mg} / \mathrm{kg}$, intraperitoneally (i.p.), at 2-h intervals] or saline. Behavioral assessments were performed $3 \mathrm{~d}$ and $14 \mathrm{~d}$ after the final MA injection. Mice were sacrificed immediately for neurochemical evaluations after behavioral assessments. Additional mice were sacrificed $4 \mathrm{~h}$ after the final MA

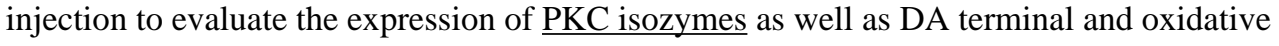


stress markers. (A and B). ICR mice received a single injection of MA (35 mg/kg, i.p.) and were sacrificed $1 \mathrm{~d}$ after the treatment to determine the effect of rottlerin on apoptosis induced by MA $(\mathbf{C})$. 
A. PKC $\alpha$
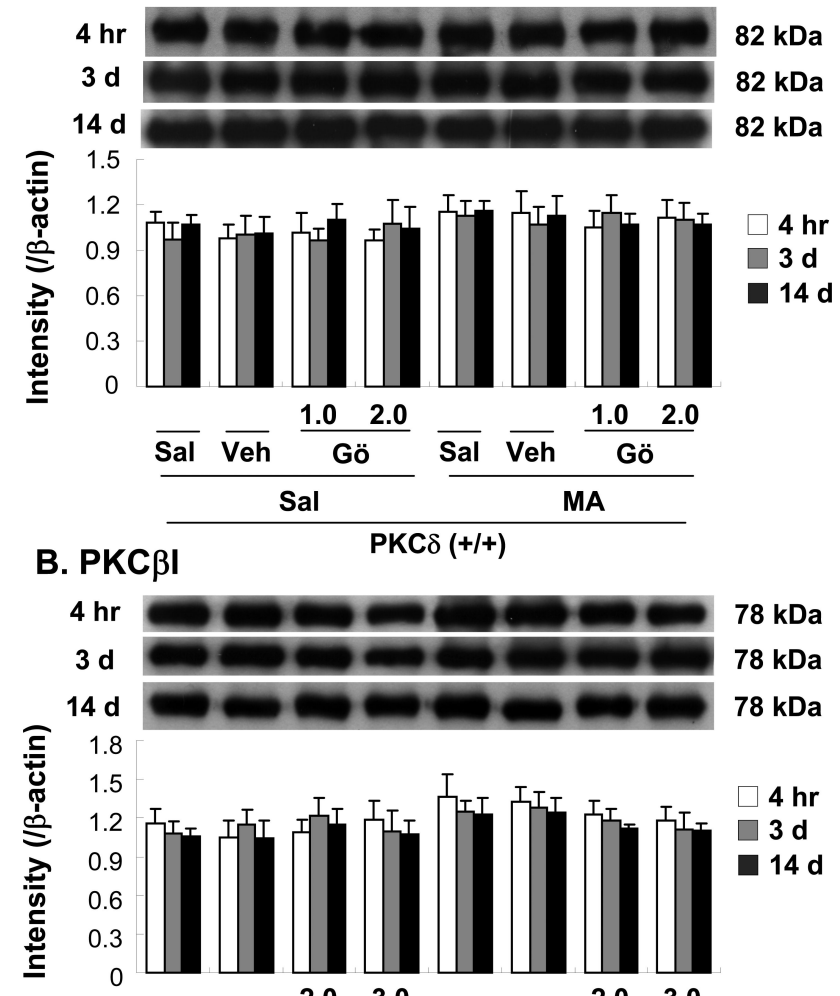

1.8
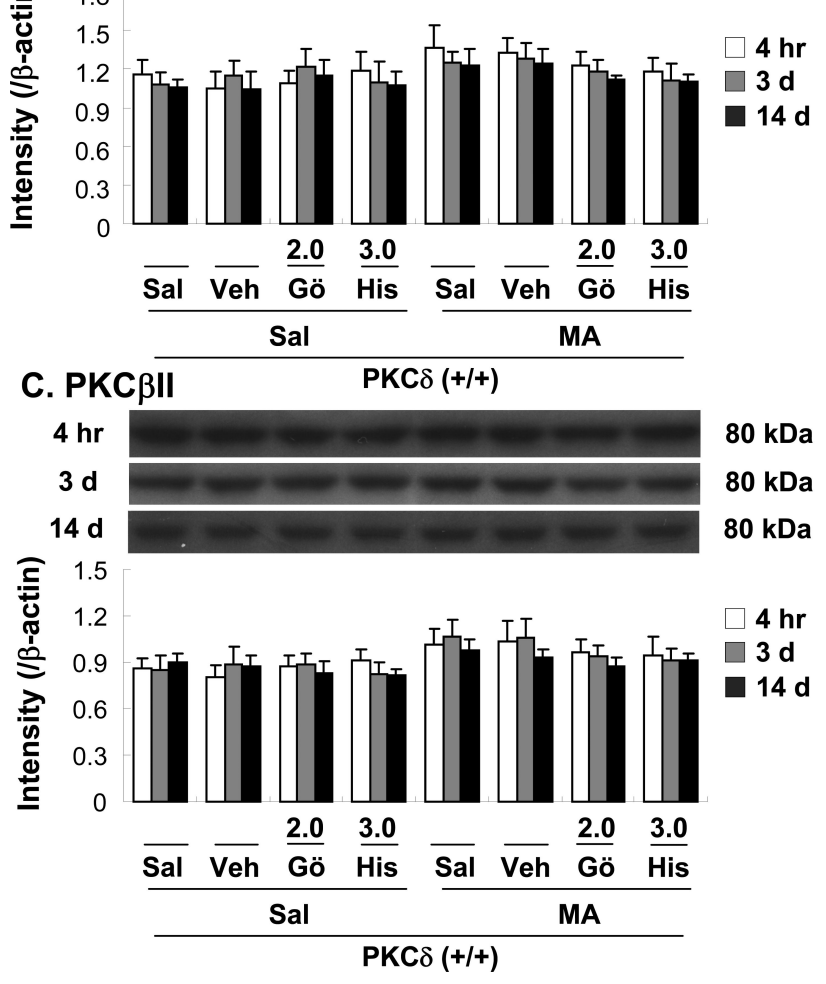


\section{PKC $\zeta$}

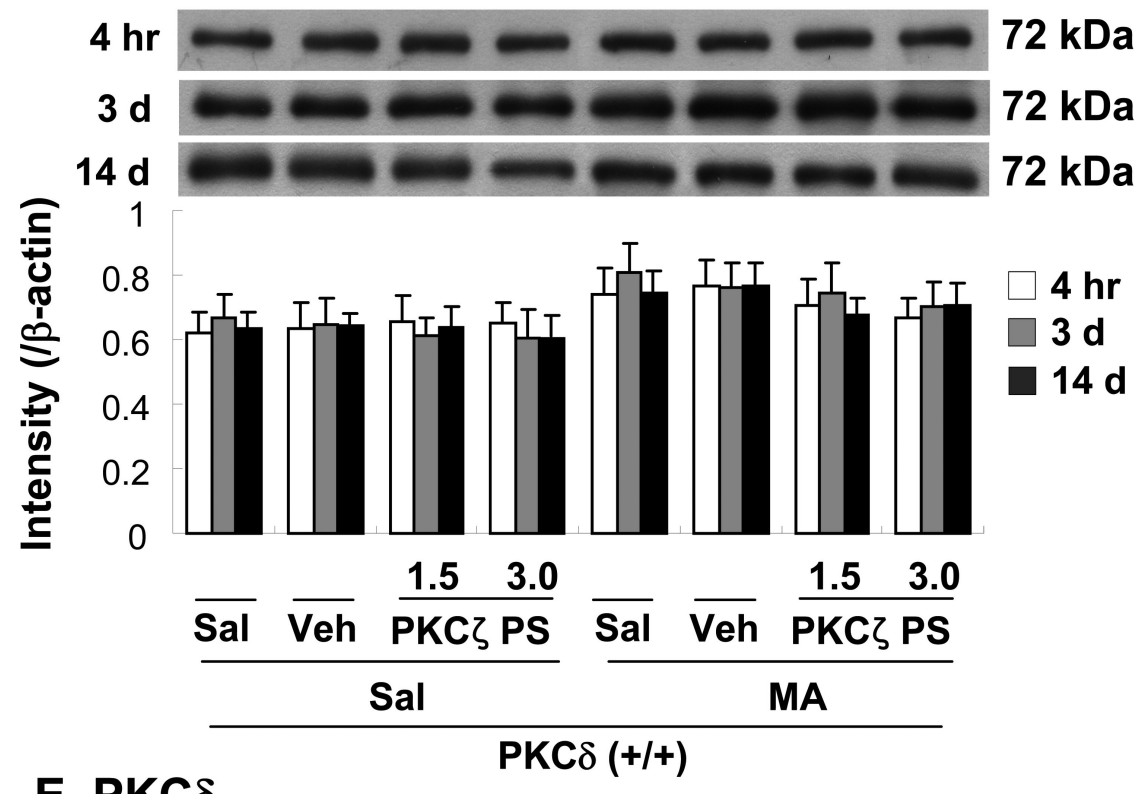

\section{E. PKC $\delta$}

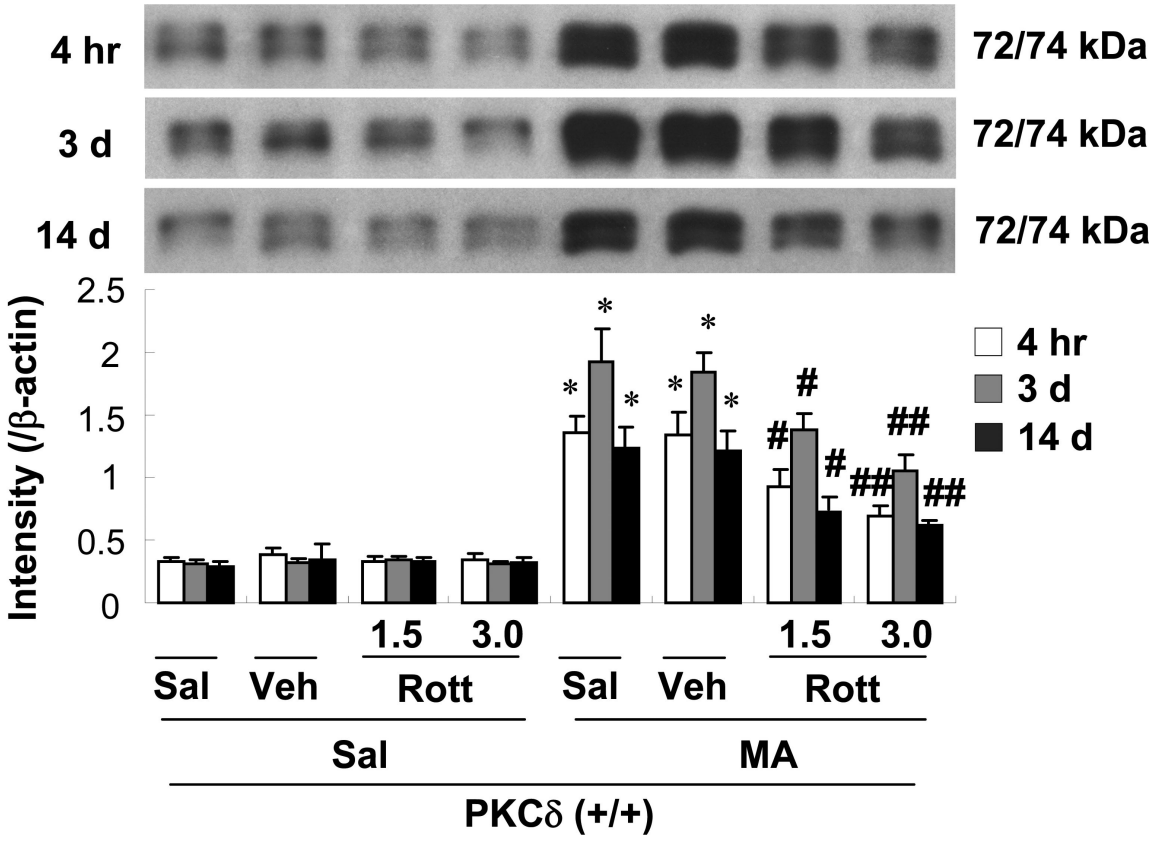

Fig. 2.

Changes in protein expression of PKCa (A), PKC $\beta \mathrm{I}(\mathbf{B}), \mathrm{PKC} \beta \mathrm{II}(\mathbf{C}), \mathrm{PKC} \zeta(\mathbf{D})$, and $\mathrm{PKC} \delta$ (E) in the mouse striatum at $4 \mathrm{~h}, 3 \mathrm{~d}$, and $14 \mathrm{~d}$ after the final methamphetamine (MA) administration. $\mathrm{Sal}+\mathrm{Sal}=$ saline, intracerebroventricularly (i.c.v.) + saline (i.p.). Vehicle $(10 \% \mathrm{DMSO})=$ Veh. $\mathrm{Veh}+\mathrm{Sal}=$ vehicle (i.c.v. $)+$ saline (i.p.); $\mathrm{Sal}+\mathrm{MA}=$ saline (i.c.v. $)+$ MA (i.p.). Veh + MA = vehicle (i.c.v.) + MA (i.p.). Gö 1.0 or Gö $2.0=$ Gö6976 at a dose of 1.0 or $2.0 \mu$ g, i.c.v.; His $3.0=$ hispidin at a dose of $3.0 \mu$ g, i.c.v.; PKC $\zeta$ PS 1.5 or PKC $\zeta$ PS $3.0=$ PKC $\zeta$ pseudosubstrate inhibitor at a dose of 1.5 or $3.0 \mu$ g, i.c.v.; Rott 1.5 or Rott $3.0=$ rottlerin at a dose of 1.5 or $3.0 \mu \mathrm{g}$, i.c.v.. Each value is the mean \pm standard error of the 
mean (S.E.M.) of $\underline{6 \text { to } 10 \text { animals. }}{ }^{*} P<0.01$ vs. Sal + Sal. ${ }^{\#} P<0.05,{ }^{\# \#} P<0.01 v s$. Veh + MA (one-way ANOVA followed by Fisher's PLSD test). 


\section{A. Locomotor activity}

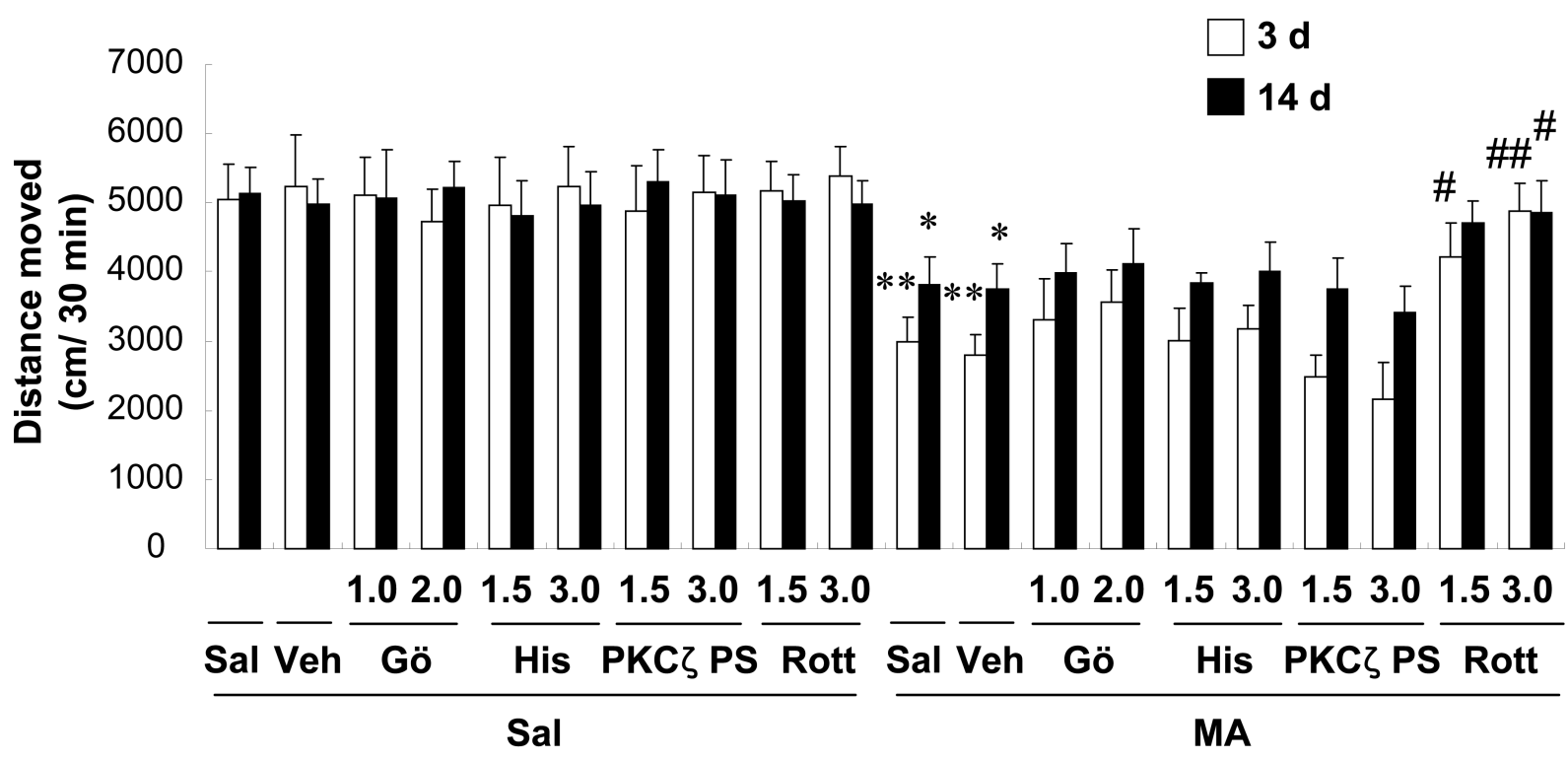

\section{B. Rota-rod test}

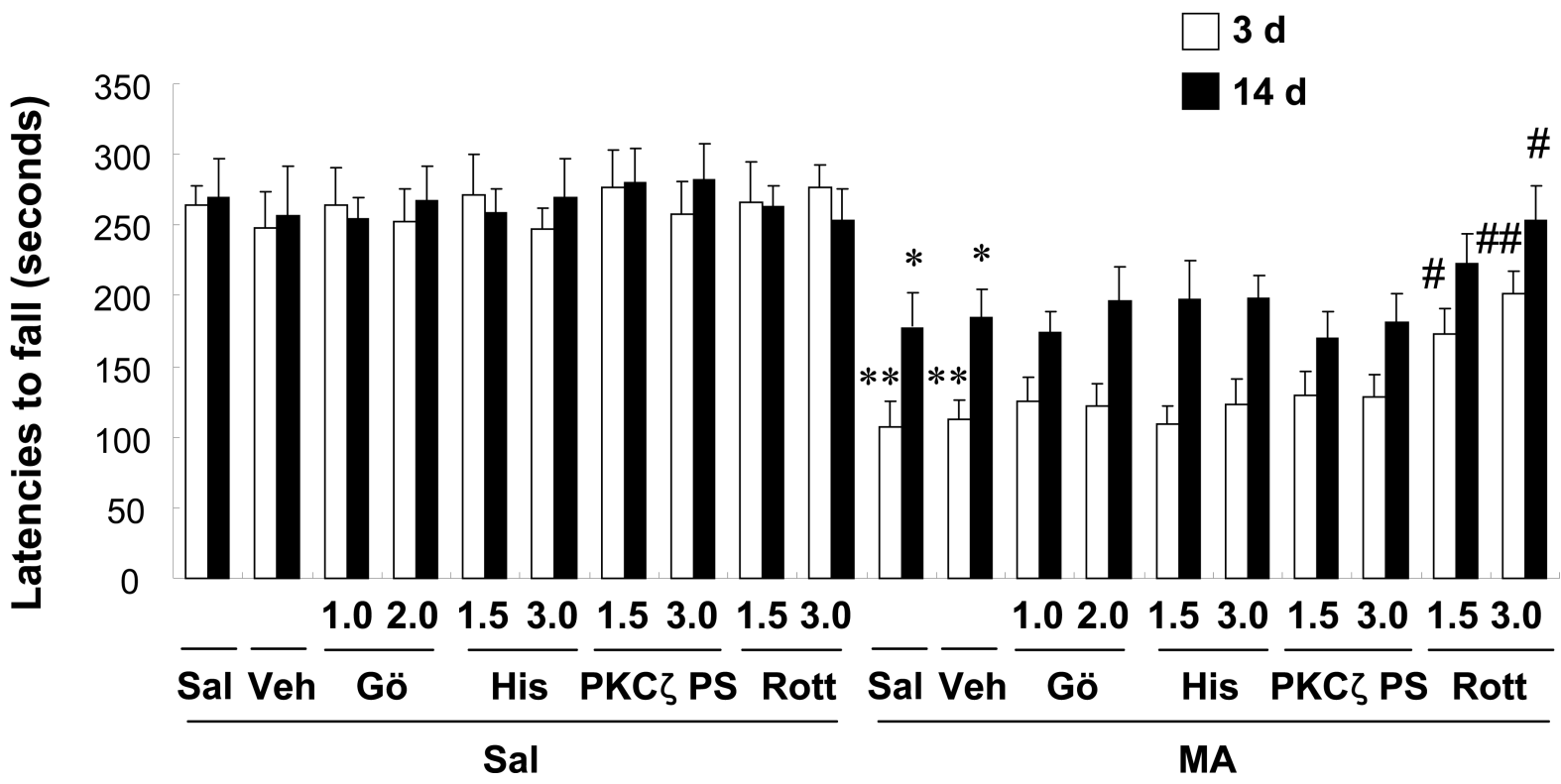

Fig. 3.

Effects of Gö6976 (a co-inhibitor of PKCa and - $\beta$ ), hispidin (a PKC $\beta$ inhibitor), PKC $\zeta$ pseudosubstrate inhibitor (a PKC $\zeta$ inhibitor), and rottlerin (a PKC $\delta$ inhibitor) on locomotor activity (A) and rota-rod performance (B) $3 \mathrm{~d}$ and $14 \mathrm{~d}$ after the final methamphetamine (MA) treatment. Sal $+\mathrm{Sal}=$ saline (i.c.v. $)+$ saline (i.p.); Vehicle $(10 \% \mathrm{DMSO})=$ Veh. $\underline{\text { Veh }}$ $+\mathrm{Sal}=$ vehicle (i.c.v.) + saline (i.p.). $\mathrm{Sal}+\mathrm{MA}=$ saline (i.c.v.) $+\mathrm{MA}$ (i.p.). $\underline{\mathrm{Veh}}+\mathrm{MA}=$ vehicle (i.c.v.) + MA (i.p.). Gö 1.0 or Gö $2.0=$ Gö6976 at a dose of 1.0 or $2.0 \mu$ g, i.c.v.; His $3.0=$ hispidin at a dose of $3.0 \mu \mathrm{g}$, i.c.v.; $\mathrm{PKC} \zeta$ PS 1.5 or PKC $\zeta$ PS $3.0=\mathrm{PKC} \zeta$

pseudosubstrate inhibitor at a dose of 1.5 or $3.0 \mu \mathrm{g}$, i.c.v.; Rott 1.5 or Rott $3.0=$ rottlerin at a 
dose of 1.5 or $3.0 \mu \mathrm{g}$, i.c.v.. Each value is the mean \pm S.E.M. of $\underline{12-18}$ animals. $* P<0.01$ vs. Sal + Sal. ${ }^{\#} P<0.05,{ }^{\# \#} P<0.01$ vs. Veh + MA (one-way ANOVA followed by Fisher's PLSD test). 
A.
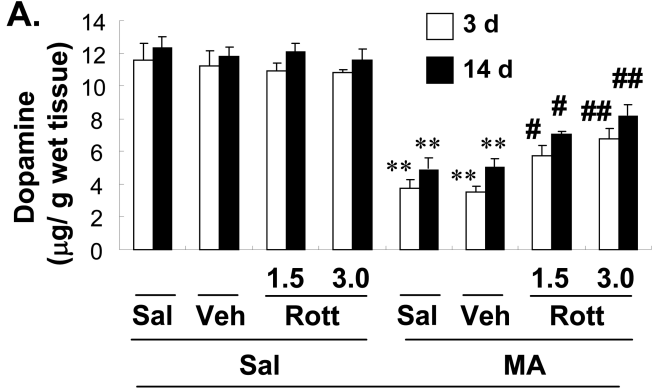

c.
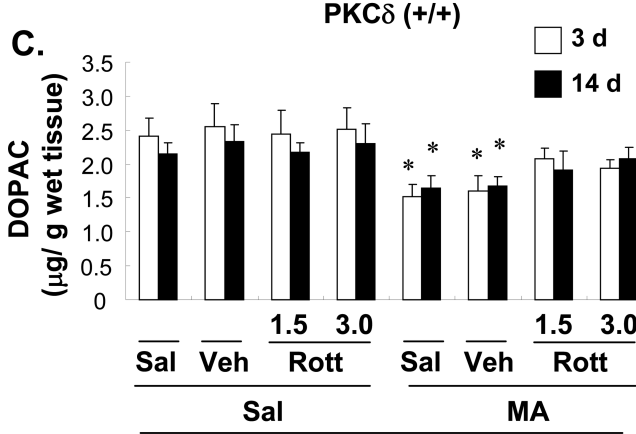

G.
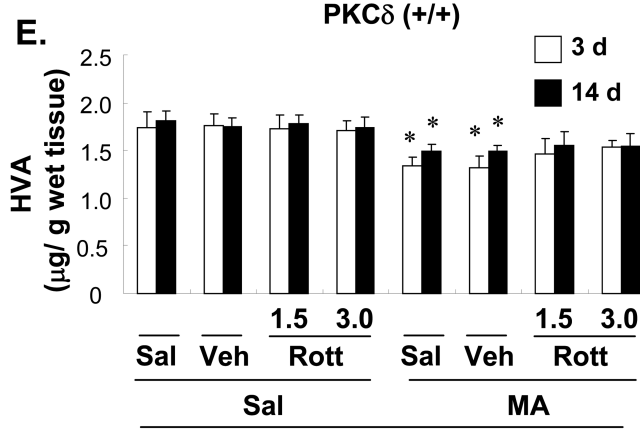

$\operatorname{PKC} \delta(+/+)$

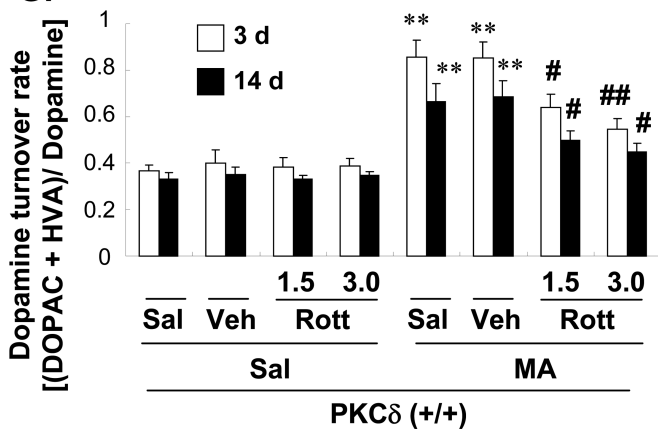

Fig. 4.

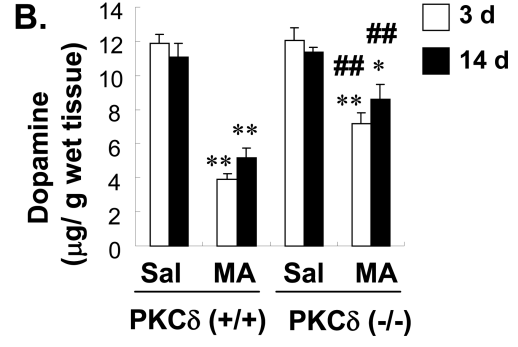

D.

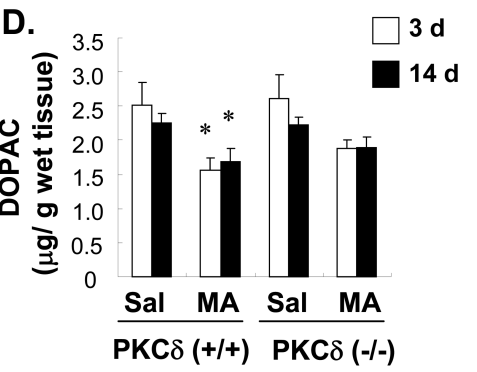

F.

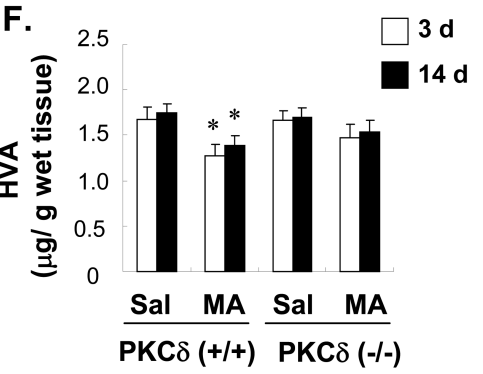

H.

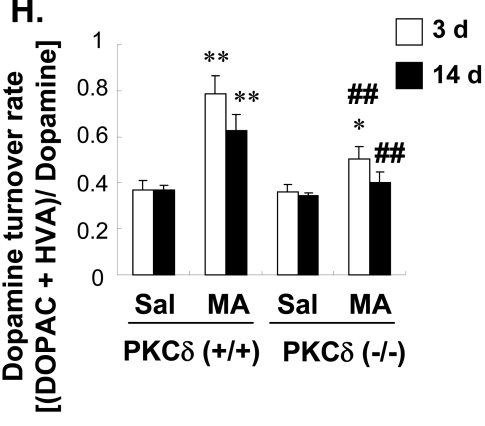

Effect of rottlerin $(\mathbf{A}, \mathbf{C}, \mathbf{E}$, and $\mathbf{G})$ or $P K C \delta$ gene knockout $(\mathbf{B}, \mathbf{D}, \mathbf{F}$, and $\mathbf{H})$ on changes in dopamine (A and $\mathbf{B}$ ), 3,4-dihydroxyphenylacetic acid (DOPAC; $\mathbf{C}$ and $\mathbf{D})$, homovanillic acid (HVA; $\mathbf{E}$ and $\mathbf{F})$, and the dopamine turnover rate $(\mathbf{G}$ and $\mathbf{H})$ in the mouse striatum $\underline{3 \mathrm{~d}}$ and $14 \mathrm{~d}$ after the final methamphetamine (MA) administration. Sal $=$ Saline. Vehicle $(10 \%$ DMSO) $=$ Veh. Rott 1.5 or Rott $3.0=$ rottlerin, a PKC $\delta$ inhibitor at a dose of 1.5 or $3.0 \mu \mathrm{g}$, i.c.v.. Each value is the mean \pm standard error of the mean (S.E.M.) of six animals. ${ }^{*} P<$ $0.05,{ }^{* *} P<0.01 v s$. corresponding saline-treated mice. ${ }^{\#} P<0.05,{ }^{\# \#} P<0.01 v s$. Veh + MAor MA-treated PKC $\delta(+/+)$ mice (one-way ANOVA followed by Fisher's PLSD test). 
A.

$3 \mathrm{~d}$

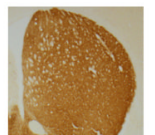

$14 \mathrm{~d}$
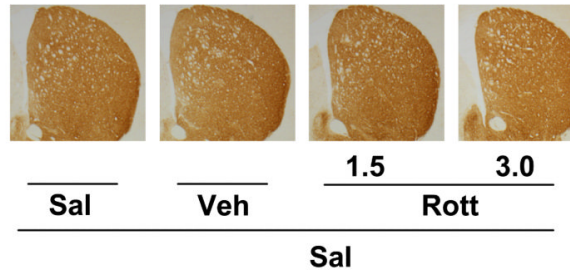
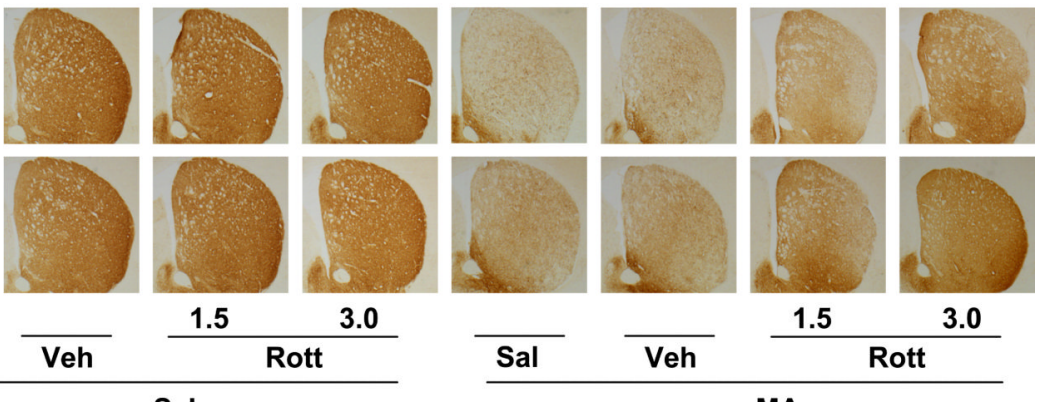

$\overline{\text { Veh }}$
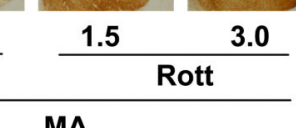

\section{PKC $\delta(+/+)$}

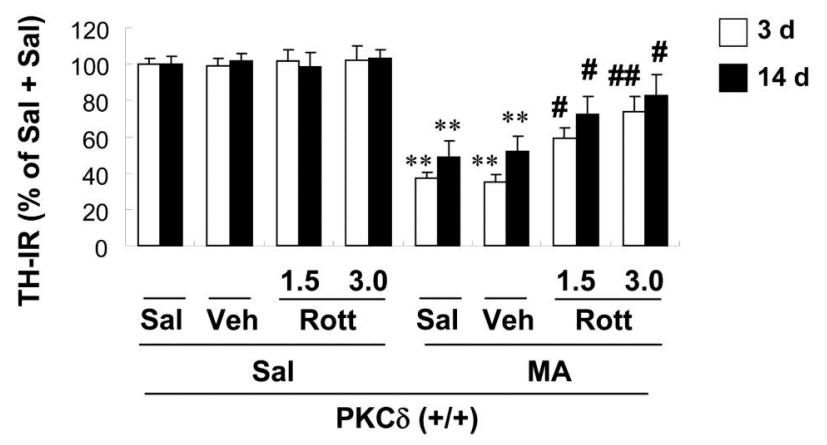

B.
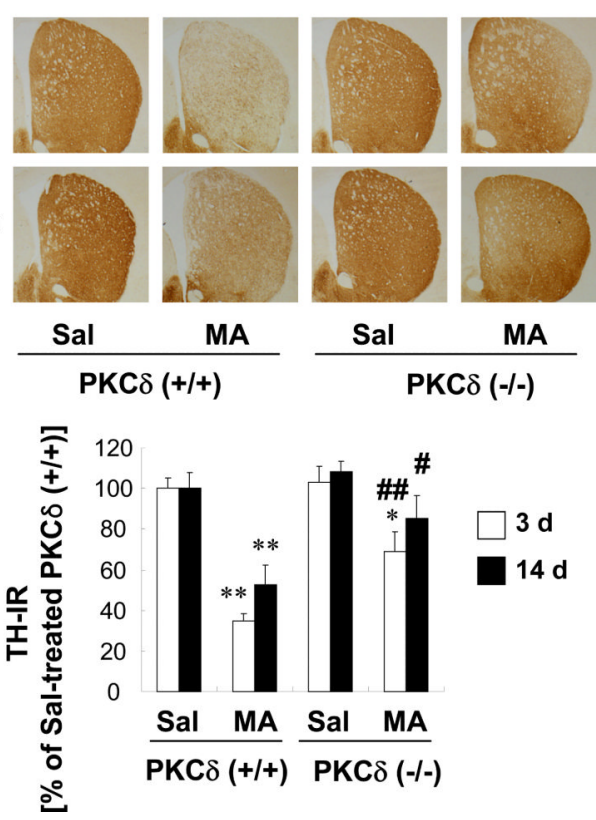
C.

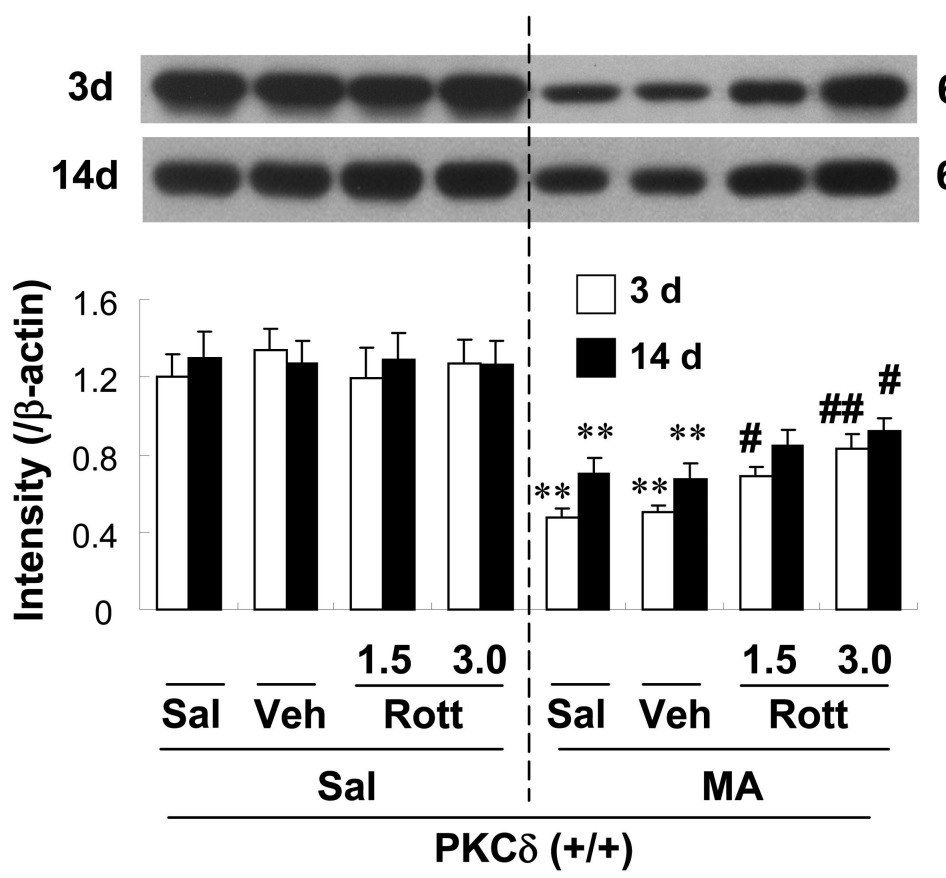

E.

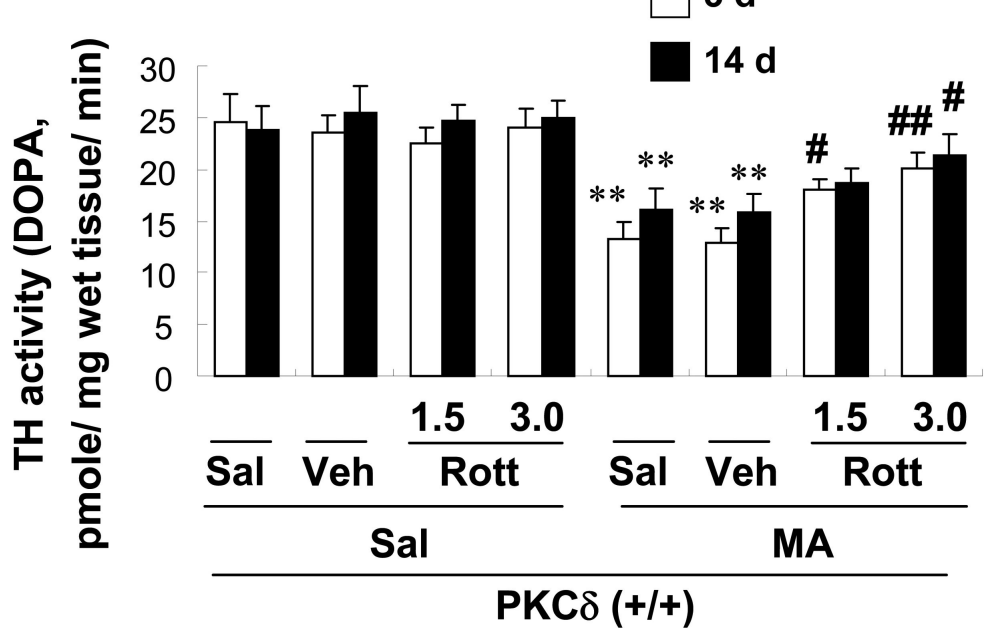

D.

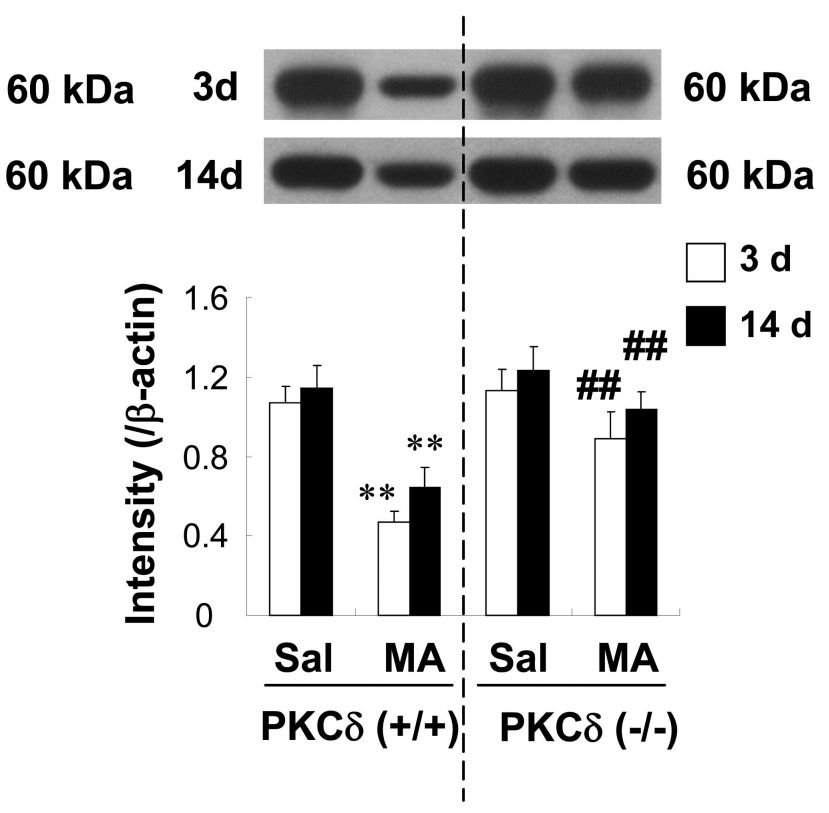

F.

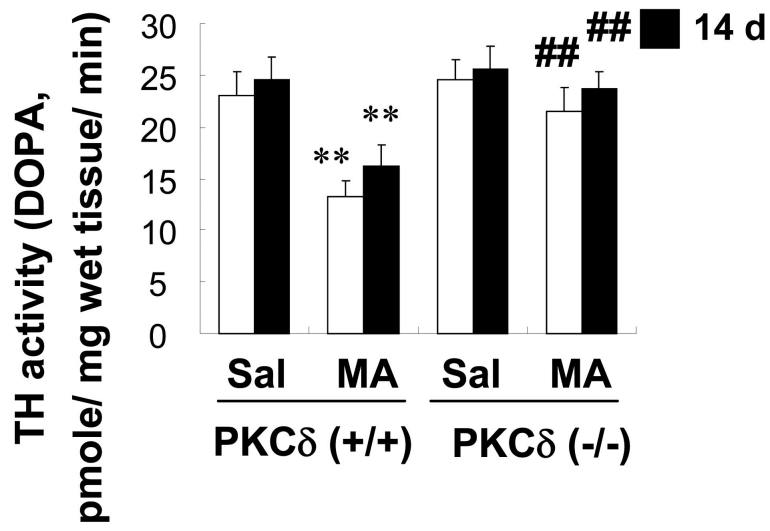

Fig. 5.

Effect of rottlerin (1.5 or $3.0 \mu$ g, i.c.v.; $\mathbf{A}, \mathbf{C}$, and $\mathbf{E})$ or $P K C \delta$ gene knockout $(\mathbf{B}, \mathbf{D}$, and $\mathbf{F})$ on the decrease in tyrosine hydroxylase (TH) immunoreactivity (IR; $\mathbf{A}$ and $\mathbf{B}$ ), TH protein expression ( $\mathbf{C}$ and $\mathbf{D})$, and $\mathrm{TH}$ activity $(\mathbf{E}$ and $\mathbf{F})$ in the mouse striatum $3 \mathrm{~d}$ and $14 \mathrm{~d}$ after the final methamphetamine (MA) administration. Sal $=$ Saline. Vehicle $(10 \%$ DMSO $)=$ Veh. Rott 1.5 or Rott $3.0=$ rottlerin, a PKC $\delta$ inhibitor at a dose of 1.5 or $3.0 \mu$ g, i.c.v.. Each value is the mean \pm standard error of the mean (S.E.M.) of 6 to 10 animals. $* P<0.05, * * P<0.01$ vs. corresponding saline-treated mice. ${ }^{\#} P<0.05,{ }^{\# \#} P<0.01$ vs. Veh + MA- or MA-treated PKC $\delta(+/+)$ mice (one-way ANOVA followed by Fisher's PLSD test). 


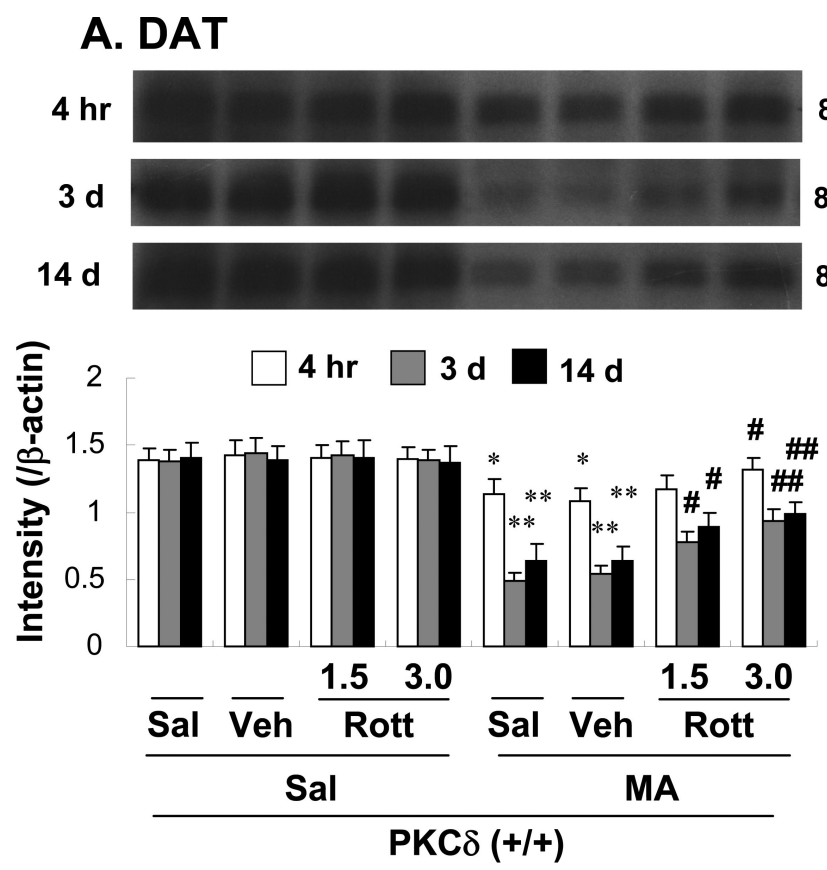

\section{B. DAT}

\section{VMAT2}

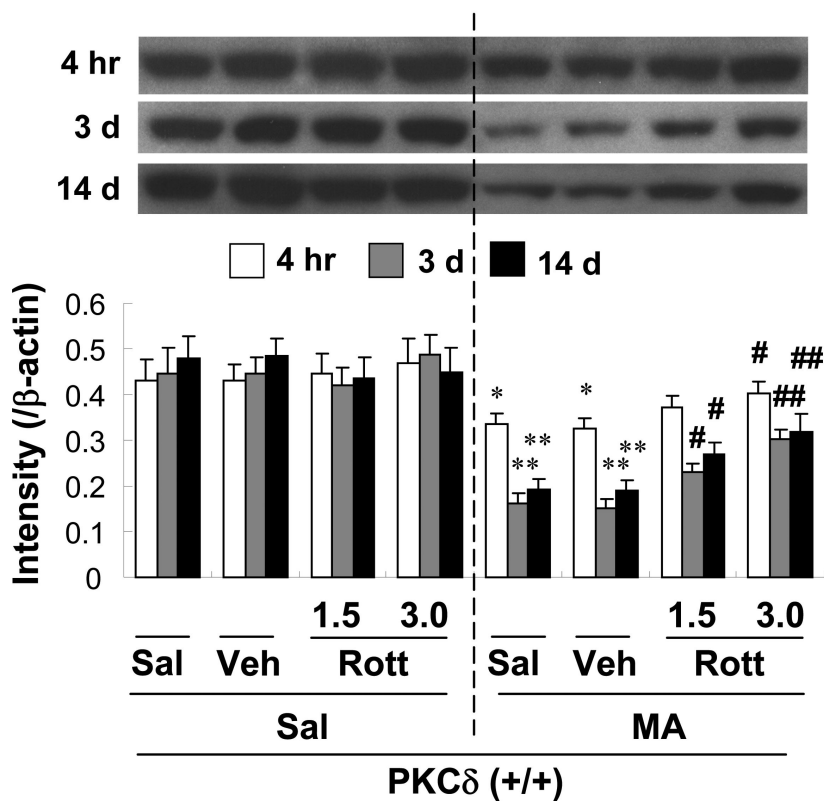

$80 \mathrm{kDa}$

$80 \mathrm{kDa}$ $80 \mathrm{kDa}$

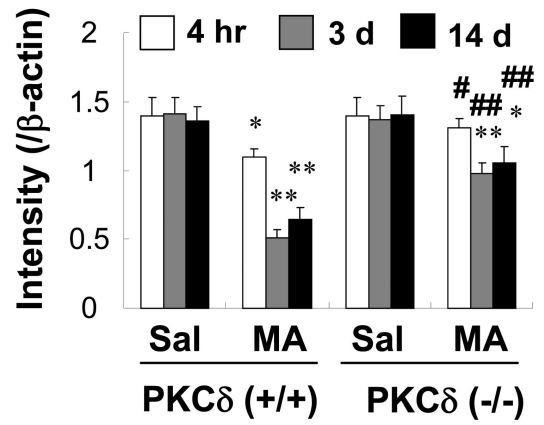

$80 \mathrm{kDa}$

$80 \mathrm{kDa}$

$80 \mathrm{kDa}$

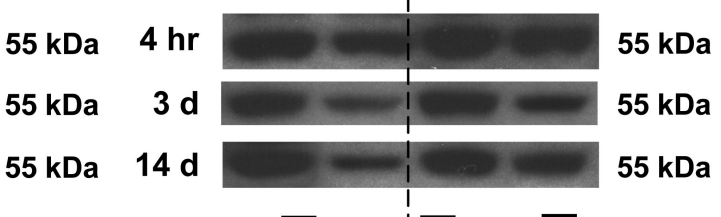

Fig. 6.

Effect of rottlerin (1.5 or $3.0 \mu$ g, i.c.v.; $\mathbf{A}$ and $\mathbf{C})$ or $P K C \delta$ gene knockout $(\mathbf{B}$ and $\mathbf{D})$ on the decrease in dopamine transporter (DAT) (A and $\mathbf{B}$ ) and vesicular monoamine transporter 2 (VMAT2) (C and D) protein expression in the synaptosomal fraction of the mouse striatum at $4 \mathrm{~h}, 3 \mathrm{~d}$, and $14 \mathrm{~d}$ after the final methamphetamine (MA) administration. Sal = Saline. Vehicle $(10 \%$ DMSO $)=$ Veh. Rott 1.5 or Rott $3.0=$ rottlerin, a PKC $\delta$ inhibitor at a dose of 1.5 or $3.0 \mu \mathrm{g}$, i.c.v.. Each value is the mean \pm standard error of the mean (S.E.M.) of 6 to 10 animals. ${ }^{*} P<0.05,{ }^{* *} P<0.01 v s$. corresponding saline-treated mice. ${ }^{\#} P<0.05,{ }^{\# \#} P<0.01$ 
$v s$. Veh + MA- or MA-treated PKC $\delta(+/+)$ mice (one-way ANOVA followed by Fisher's PLSD test). 


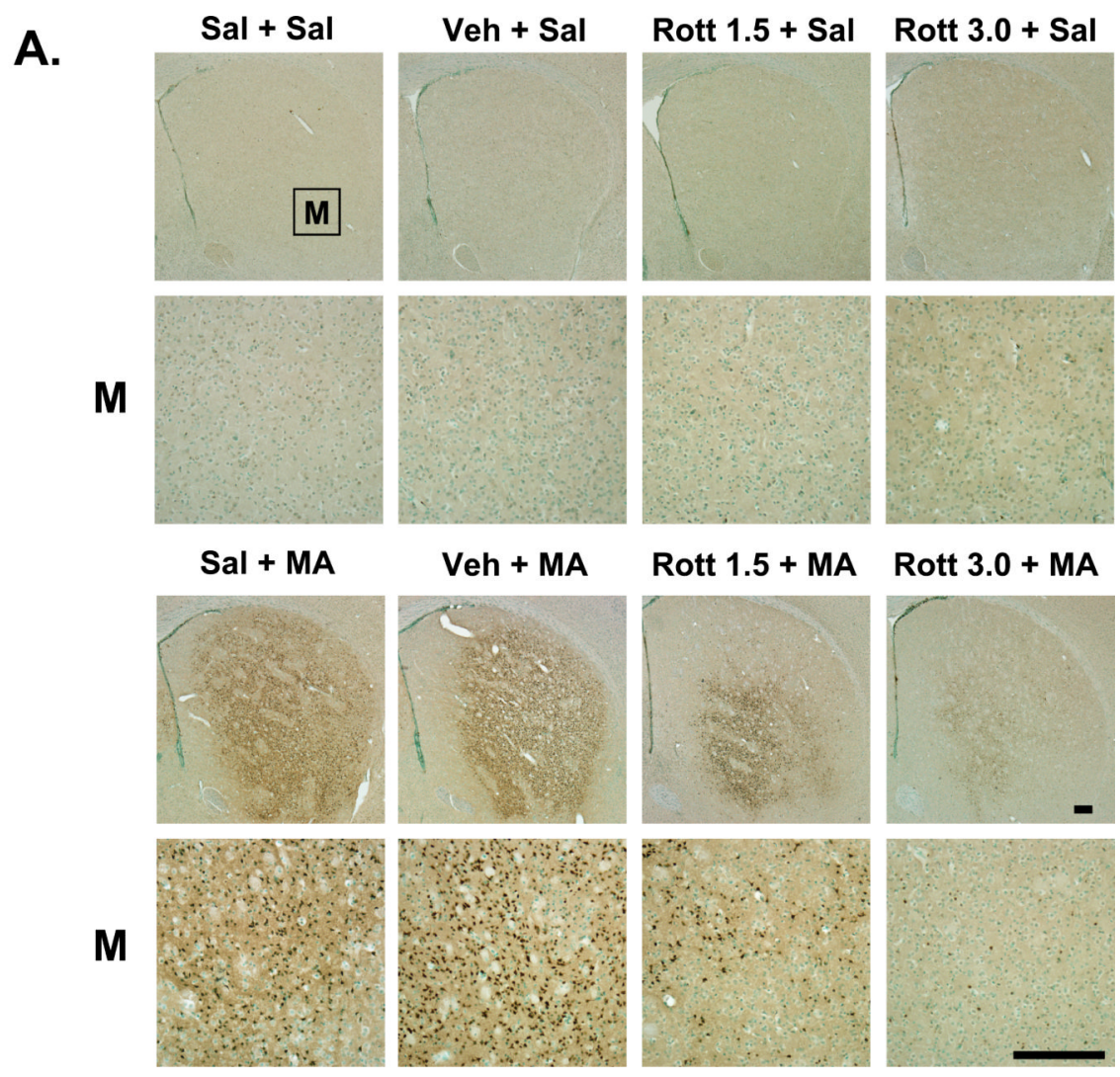

B.

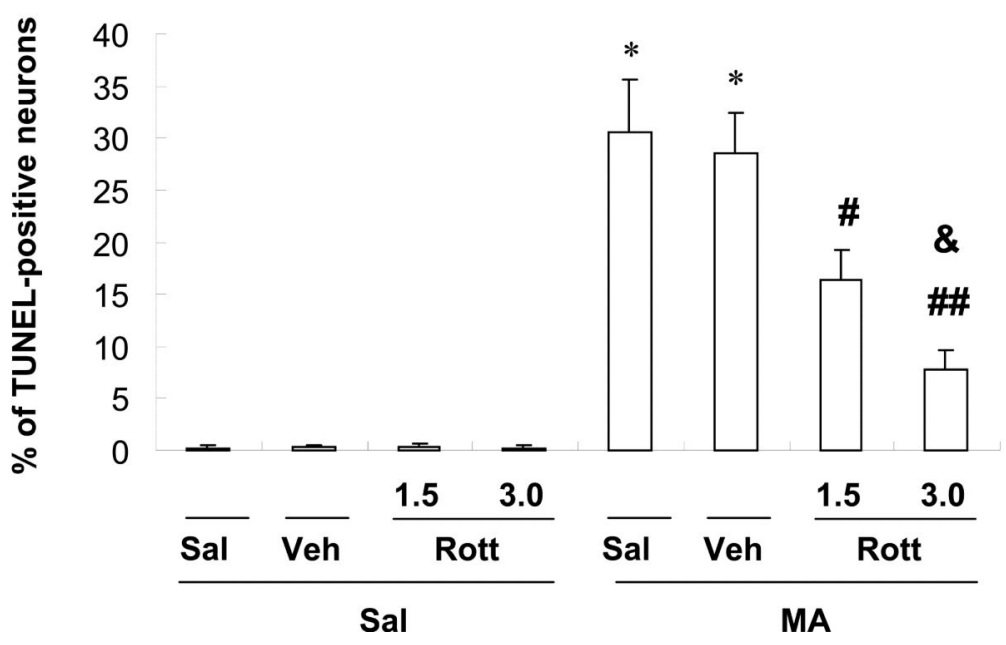

Fig. 7.

Effect of rottlerin (1.5 or $3.0 \mu$ g, i.c.v.) on methamphetamine (MA)-induced apoptosis in mice. Mice received a single injection of MA at $35 \mathrm{mg} / \mathrm{kg}$ (i.p.) and were sacrificed at $1 \mathrm{~d}$ after methamphetamine (MA) treatment. Representative photomicrographs of terminal deoxynucleotidyl transferase-mediated dUTP nick-end labeling (TUNEL)-positive neurons in the striatum of mice treated with MA. M = magnification. Scale bar $=200 \mu \mathrm{m}(\mathbf{A})$. TUNEL-positive cells were counted as described (54) (B). Sal = Saline. Vehicle (10\% DMSO $)=$ Veh. Rott 1.5 or Rott $3.0=$ rottlerin, a PKC $\delta$ inhibitor at a dose of 1.5 or $3.0 \mu \mathrm{g}$, i.c.v.. Each value is the mean \pm standard error of the mean (S.E.M.) of six animals. ${ }^{*} P P<$ $0.01 v s$. corresponding saline-treated mice. ${ }^{\#} P<0.05,{ }^{\# \#} P<0.01 v s$. Veh + MA-treated 
PKC $\delta(+/+)$ mice, ${ }^{\&} P<0.05 v s .1 .5 \mu \mathrm{g}$ rottlerin + MA-treated PKC $\delta(+/+)$ mice (one-way ANOVA followed by Fisher's PLSD test). 

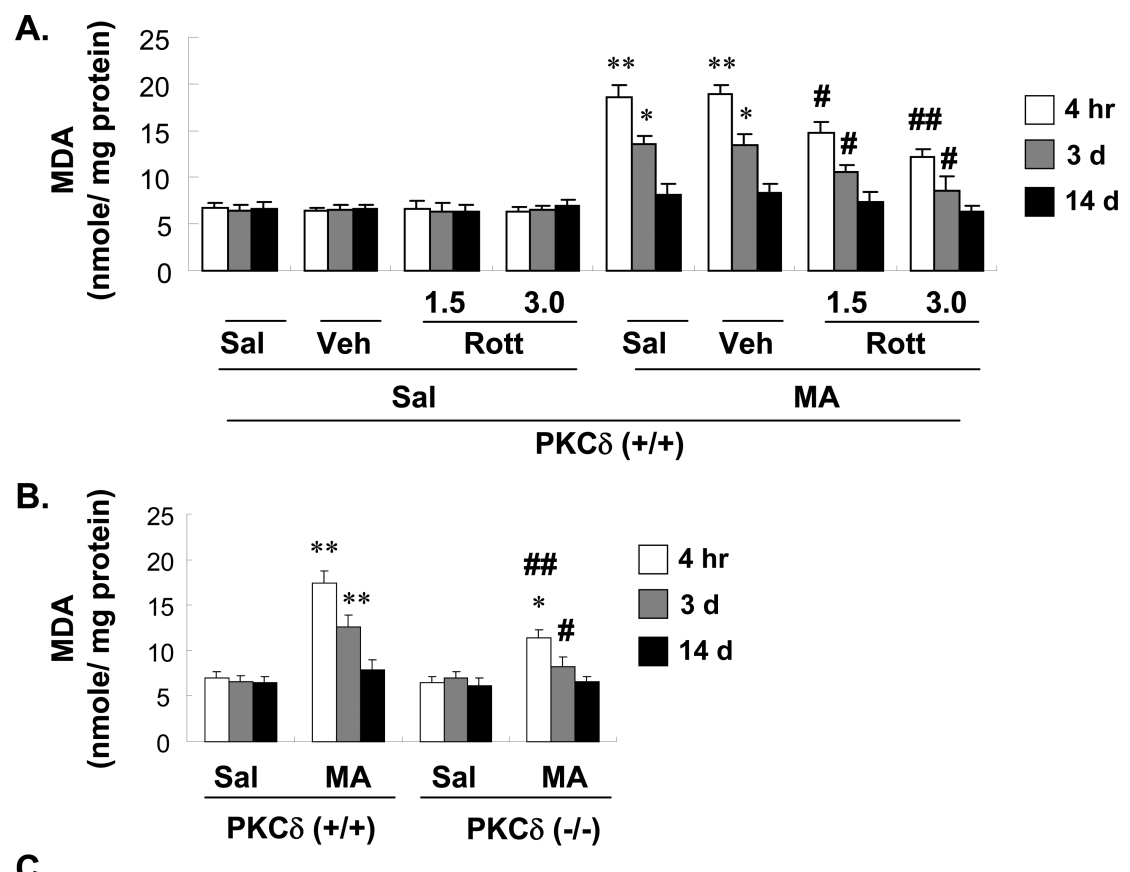

c.

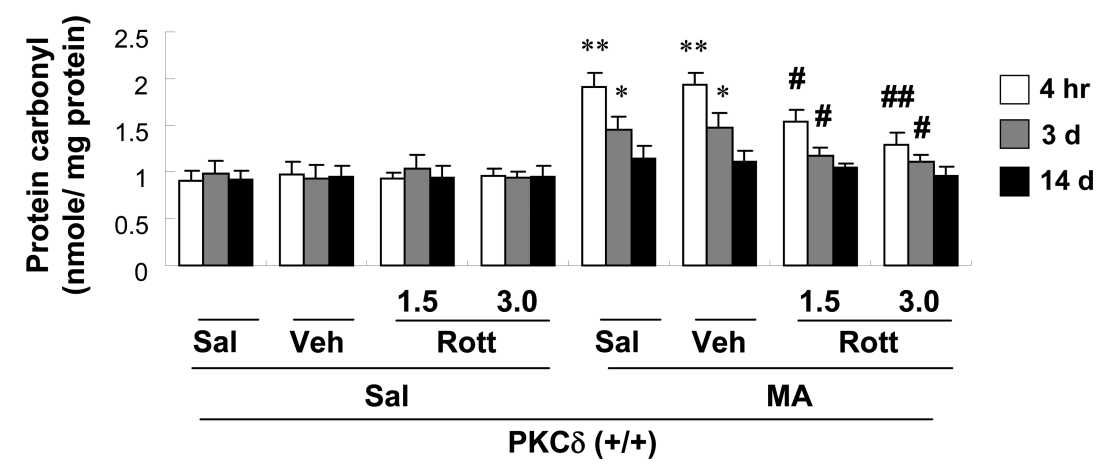

D.

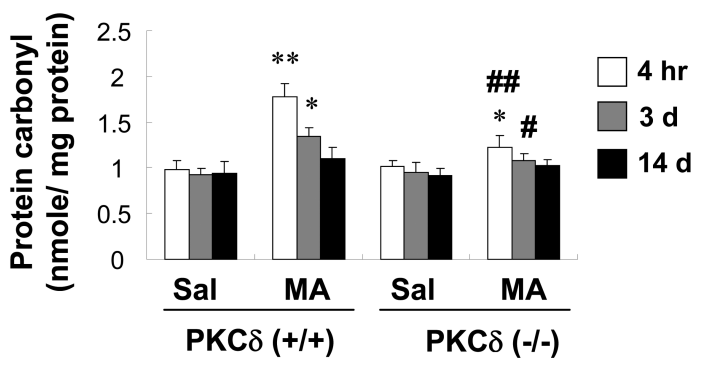



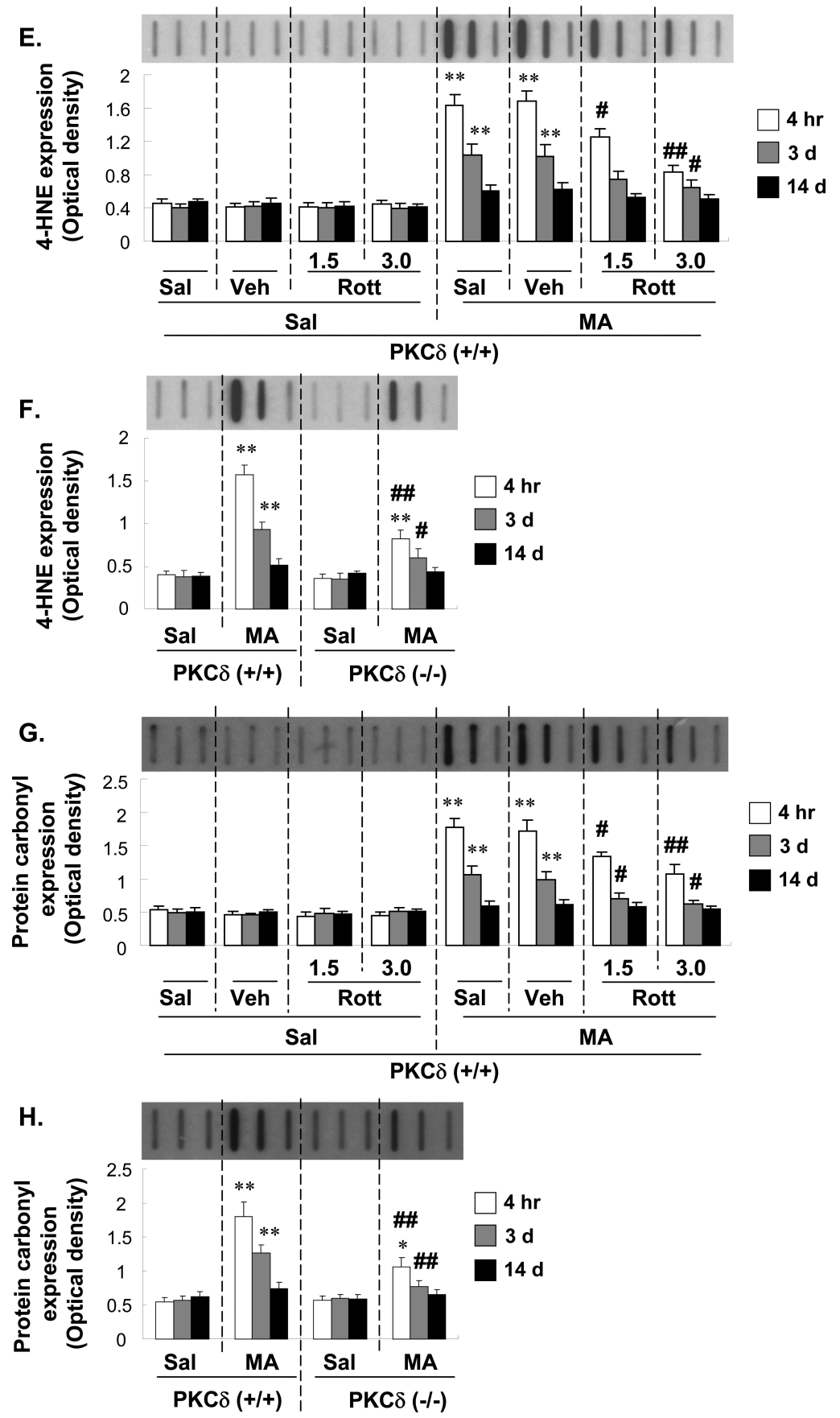

Fig. 8.

Effect of rottlerin (1.5 or $3.0 \mu \mathrm{g}$, i.c.v.; $\mathbf{A}, \mathbf{C}, \mathbf{E}$, and $\mathbf{G})$ or $P K C \delta$ gene knockout $(\mathbf{B}, \mathbf{D}, \mathbf{F}$, and $\mathbf{H}$ ) on changes in lipid peroxidation [as shown by the malondialdehyde level ( $\mathbf{A}$ and $\mathbf{B})$ and 4-HNE expression $(\underline{\mathbf{E} \text { and } \mathbf{F})]}$ and protein oxidation [as shown by protein carbonyl content $(\underline{\mathbf{C} \text { and } \mathbf{D}})$ and protein carbonyl expression $(\mathbf{G}$ and $\mathbf{H})]$ in the mouse striatum at $\underline{4 \mathrm{~h}}$,

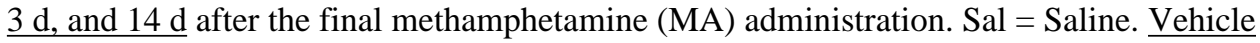
$(10 \%$ DMSO $)=$ Veh. Rott 1.5 or Rott $3.0=$ rottlerin, a PKC $\delta$ inhibitor at a dose of 1.5 or 3.0 $\mu \mathrm{g}$, i.c.v.. Each value is the mean \pm standard error of the mean (S.E.M.) of 6 to 10 animals. ${ }^{*} P<0.05,{ }^{* *} P<0.01$ vs. corresponding saline-treated mice. ${ }^{\#} P<0.05,{ }^{\# \#} P<0.01 v s$. Veh + MA- or MA-treated PKC $\delta(+/+)$ mice (one-way ANOVA followed by Fisher's PLSD test). 